\title{
Geçmiş Olsun Dileklerini İleten Mensur ve Manzum Metinler: Iyâdetnâme ve Sihhatnâmeler*
}

\author{
Betül Sinan Nizam**
}

The Prose and Verse Texts Conveying Wishes of Good Health: Iyadetnamas and Sihhatnamas

\begin{abstract}
To date, studies of texts written for ill or recovering patrons or intimate friends have focused predominantly on shhatnamas, while iyadetnamas have been overlooked. In fact, Ottoman artists not only wrote poems in the genre of sihhatnama, they also wrote letters named yyadetnama, written to wish good health especially to their patrons who were sick or recently recovered from an illness. This article asserts that these prose and verse texts, produced with similar intentions, should be examined together in order to grasp all aspects of the texts. For this reason, sihhatnama and 1yadetnama examples are examined through cross referencing their contextual, structural and expressional aspects. The relationship of the sihhatnamas and ryadetnamas to the duanamas and official Ottoman documents (telhises), which were produced with similar motivations, has also been made clear. As a result, it is revealed that these texts, which were produced within the same tradition, despite some differences, are shaped around a similar structure. In other words, they share a common discourse.
\end{abstract}

Keywords: Sihhatnama, 1yadetnama, duanama, telhis, letters, the art of prose writing.

\section{Giriş}

Osmanlı toplumunda hastalıklar ve tedavi süreçleriyle ilgili pek çok tıp eseri kaleme alınmış, ${ }^{1}$ bunun yanı sıra bu süreç edebî eser yazma geleneğinde de karşı-

* Makaleyi okuyan ve değerli önerilerde bulunan Hatice Aynur'a teşekkür ederim.

** İstanbul Şehir Üniversitesi.

1 Bununla ilgili şu makale ve tezlere bakılabilir: Zühal Kültüral ve Aylin Koç, "Ruhsal Hastalıklara Dair Bir Risâle: Sevdâ-yı Merâkiyye”, Türk Kültürü İncelemeleri Dergisi, 30 (2014), 
lığını bulmuştur. Zira sanatçılar bir taraftan padişah, devlet görevlileri ya da dostlarına hastalanmaları veya sağlıklarına kavuşmaları üzerine ıyâdetnâme adı verilen mektuplar yazarken diğer yandan sıhhatnâme türünde manzumeler kaleme alarak bunları hasta olan ve/veya şifa bulan zatlara sunmuşlardır. Bunda ıyâdetin yani hastanın hâlini hatırını sormanın ve ziyaretinin Hz. Peygamber tarafından önemsenen ve teşvik edilen bir uygulama olmasının etkisi olmalıdır. ${ }^{2}$ Nitekim iyi birer Müslüman olan ya da en azından dindeki kaide ve pratiklerden haberdar olan şair ve yazarlar bunları sosyal yaşamlarına yansıtmakla kalmamış metin üretme sürecinde de bu kural ve uygulamalardan yararlanmış, hatta üretim faaliyetlerini bunlar üzerine bina etmişlerdir. Bu şekilde asıl gayeleri olan câize, mansıb ve himaye gibi çeşitli taleplerini dinî pratikler/referanslar çerçevesinde memdûhlarına iletme fırsatı elde etmişlerdir.

Bugüne kadar ıyâdetnâmelerle ilgili müstakil bir çalışma yapılmazken sıhhatnâmelerin özelliklerini inceleyen nitelikli makaleler kaleme alınmış, türün tespit edilebilen örnekleri listelenmiş ve/veya değerlendirilmiştir. Mehmet Arslan, Halûk Gökalp ve Bahir Selçuk tarafından kaleme alınan bu makalelerde ${ }^{3}$

s. 217-44; Gülhan Atnur, "Osmanlı Tıp Yazmaları ile Halk Hekimliğinde 'Hafakan (Afakan)' ve Hazâa 'İlâc-1 Huafakân Adlı Kitap”, Uluslararası Sosyal Araştırmalar Dergisi, IV/17 (2011), s. 48-62; Ahmet Naim Çiçekler ve Mehmet Gürlek, "Osmanlı Tip Metinlerinde Geçen Hastalık Adları Üzerine”, Turkish Studies-International Periodical for the Languages, Literature and History of Turkish and Turkic, XI/21 (2016), s. 95-112; Necdet Okumuş, "Muhammed bin Mahmûd Şirvânînnin (XV. Yüzyıl) Göz Hastalıklarına Ait "Mürşîd" Adlı Eseri (İnceleme-Metin-Sözlük-İndeks)” (doktora tezi), Ege Üniversitesi Sağllk Bilimleri Enstitüsü, 1998; Emel Kaya, "Mu(h)yîddin Mehînnin Müfîd (Nazmü’t-Teshîl) Adlı Eseri (İnceleme-Metin-Dizin) ve Bu Eserin XV. Yüzyıl Türk Tıp Dilinin Oluşmasındaki Yeri” (doktora tezi), Selçuk Üniversitesi SBE, 2008.

2 Hz. Peygamber ıyâdetin Müslümanın Müslüman üzerindeki beş hakkından biri olduğunu söylemiş, hatta Müslüman olmayan hastaları da bizzat ziyaret etmiştir. M. Yaşar Kandemir, "Ziyaret", DİA, 2013, XLIV, 498. Bu konuda ayrıntılı bilgi için ayrıca bkz. Ali Çolak, "Hasta Ziyareti İle İlgili Hadisler Bağlamında Bir İnceleme”, EKEV Akademi Dergisi, 48 (2011), s. $161-76$.

3 Mehmet Arslan, "Sıhhatnâmeler", Türkler, 2002, XI, 776-90; Halûk Gökalp, "Divan Şiirinde S.hhat-nâmeler", Türk Kültürü İncelemeleri Dergisi, 14 (2006), s. 101-30 ve "Seyyid Vehbînnin Divanında Yer Almayan Bir Kasidesi”, Turkish Studies-International Periodical for the Languages, Literature and History of Turkish and Turkic, VIII/1 (2013), s. 299-314; Bahir Selçuk, "Yeni Bir Sıhhât-nâme: Şehdînnin Sultan III. Ahmed Sıhhat-nâme’si”, Turkish Studies-International Periodical for the Languages, Literature and History of Turkish and Turkic, III/2 (2008), s. 604-16. Ayrıca Bilal Kemikli'nin divan şiirinde sağlık konusunu 
çeşitli nazım şekilleriyle söylenmiş toplam otuz dokuz manzume tespit edilmiştir. Ayrıca farklı araştırmacılar karşılaştıkları sıhhatnâmeleri çeşitli konulardaki çalışmalarında belirtmişler ve/veya bunlarla ilgili malumat vermişlerdir. ${ }^{4}$ Böylece en azından sıhhatnâmelerle ilgili detaylı bilgi (tanımı, özellikleri, muhatapları, örnekleri vb.) ortaya konmuştur. Şimdiye kadar yapılan çalışmalardan farklı olarak sıhhatnâme ve ryâdetnâmelerin birlikte değerlendirilmesi gerektiğini savunan bu makale giriş ve sonuç dışında iki bölümden oluşmaktadır. Birinci bölümde sıhhatnâme ve ıyâdetnâmelerin tanım ve kapsamları üzerinde durulmuştur. Bunların duânâme türündeki manzume ve mektuplarla Osmanlı resmî belgelerinden olan telhisler ile ilişkileri/ortak noktaları irdelenmiş, yeri geldikçe dipnotlarda literatürde sıhhatnâmelerle ilgili söylenenler değerlendirilmiştir. İkinci bölüm şimdiye kadar araştırmacılar tarafindan tespit edilen sıhhatnâmeler ile taramalarım sonucu münşeâtlarda ulaştığım ıyâdetnâmelerin çeşitli açılardan karşılaştırılmasını içerir. Farklı amaçlarla yazılan (iyileşmeyi tebrik veya şifa dileği) sıhhatnâme ve ıyâdetnâmelerin kendi içlerindeki benzerlik ve farklılıkları da yeri geldiğinde değinilen konulardandır. Sonuçta hasta ya da henüz şifa bulmuş muhataba geçmiş olsun dileklerini iletmek için yazılan ıyâdetnâme ve sıhhatnâmelerin, içinde üretildikleri kültürel ve edebî geleneğin dinamiklerinin tüm yönleriyle ortaya konabilmesi için (aynı motivasyon ve işleve sahip diğer metinler de dikkate alınarak) bir arada değerlendirilmeleri gerektiği vurgulanmıştır. Çalışmanın sonuna sıhhatnâme ve ıyâdetnâme örnekleri eklenmiştir.

\section{Tür Tartışmaları}

Az sayıda araştırmacı münşeât mecmûalarında yer alan mektuplarla divan edebiyatı nazım şekilleri arasındaki biçimsel ilişkiye dikkat çekse de ${ }^{5}$ bugüne kadar bu konuda detaylı çalışma yapılmamıştır. Hâlbuki Arap edebiyatının önemli

ele alan makalesinin küçük bir bölümü de sıhhatnâmelere ayrılmıştır. Bkz. Bilal Kemikli, "Divan Şiirinde Sağlık”, Osmanlılarda Sağlık, I, ed. Coşkun Yılmaz ve Necdet Yılmaz, (İstanbul: Biofarma, 2006), s. 306-308.

4 Sıhhatnâmelerle ilgili çalışmalarda yer almayan örnekleri listeleyip değerlendirdiğim makalemde bunlarla ilgili bilgi verilecektir.

5 Bkz. Christine Woodhead, "Ottoman Inşa and The Art of Letter-Writing Influences Upon The Career of The Nişancı and Prose Stylist Okçuzade (d. 1630)", Osmanlı Araştırmaları, VII-VIII (1988), s. 157-9; Ömer Çakır, “Türk Edebiyatında Mektup” (doktora tezi), Gazi Üniversitesi SBE, 2005, s. 68; Serkan Akalın, "Duacı Bir Baba Olarak Mevlânâ ve Mektuplarr", Turkish Studies-International Periodical for the Languages, Literature and History of Turkish and Turkic, IX/3 (2014), s. 16. 
münekkit, edip ve şairi İbn Tabâtabâ (ö. 322/934) edebî mektupla kaside arasında ilgi kurarak "edebî mektubu serbest vezinli, nesre dönüştürülmüş (mahlûl) kaside, kasideyi de şiire dönüştürülmüş (ma’kûd) risâle olarak görür ve her ikisinin bölümleri, belâgat incelikleri ve yöntemlerinin birbirine benzediğini söyler." ${ }^{6}$ Hakikaten divan edebiyatı sanatçıları mektup ile kaside vb. manzumelerde benzer konuları ele almakla kalmamışlar bunlarda benzer içerik ve yapı özelliklerini, söyleyiş biçimlerini, anlatım kalıplarını kullanmışlardır. Bu nedenle belli bir konu dâhilinde ya da bir başka deyişle belli bir amaçla yazılan metinler ele alınırken hem manzum hem mensur örnekleri incelenmelidir. Bunlar münşeât mecmûalarında ve divanlarda farklı adlarla anılsa bile yazılış gayeleri düşünüldüğünde benzer metinlerdir. Bu bakımdan muhatabın hastalık veya iyileşme haberi üzerine yazılan sıhhatnâmeler, aynı nedenlerle kaleme alınan ıyâdetnâmelerle ilişkili olarak ele alınmalıdır.

Iyâdetnâme ve sıhhatnâmelerin ilişkisi ortaya konmadan önce şair ve münşîlerin muhataplarına geçmiş olsun demek için bu ikisinden birini tercih etmelerinin sebepleri de sorgulanabilir. Başka deyişle sanatçılar muhataplarına neden sıhhatnâme yerine ryâdetnâme ya da ryâdetnâme yerine sıhhatnâme yazmışlardır? Bu soru özellikle hem divan hem münşeât sahibi sanatçılar düşünülünce daha anlamlı hâle gelir. Örneğin Çelebizâde Âsım’ın (ö. 1173/1760) münşeâtında Lütfullâh ve Nakşî Efendiler için yazılmış iki ayrı ıyâdetnâme yer alırken divanında III. Ahmed'e (salt. 1703-1730) yazılmış bir sıhhatnâme bulunmaktadır. Nâbî (ö. 1124/1712), Lâmiî (ö. 938/1532), Mesîhî (ö. 918/1512'den sonra), Nevres-i Kadîm (ö. 1175/1762) ise farklı zatlar için ıyâdetnâmeler kaleme almış ama divanlarında sıhhatnâmeye yer vermemişlerdir. Christine Woodhead Azmîzâde Hâletî̀nin (ö. 1040/1631) divanında III. Mehmed'e (salt. 1595-1603) yazılmış dört ve I. Ahmed'e (salt. 1603-1617) yazılmış yedi kaside yer almasına rağmen münşeâtında herhangi bir sultana gönderilmiş bir mektup bulunmamasını manidar bulduğunu söyler. ${ }^{8}$ Araştırmacı bir diğer makalesinde hem şair hem münşî olan kişilerin bir durumda gazel ${ }^{9}$ diğger durumda mektup yazmasının sadece

6 İsmail Durmuş, “Mektup (Arap Edebiyatı)”, DİA, 2004, XXIX, 14.

7 Sıhhatnâmelerle ilgili çalışmalarda hakkında bilgi bulunmayan bu manzumeyi daha önce bahsettiğim ikinci makalemde ele alacağım.

8 Christine Woodhead, "Yazışma Çevreleri: Onyedinci Yüzyıl Başlarında Osmanlı Mektup Yazımı”, Eski Türk Edebiyatı Çalışmaları V: Nesrin İnşâsı, haz. Hatice Aynur vd. (İstanbul: Turkuaz, 2010), s. 226.

9 Woodhead mektupların kasidelerden çok gazellerle benzerlik gösterdiğini savunmaktadır. Bunun için bkz. Woodhead, "Ottoman Inşa”, s. 157-9. 
mesafe bakımından yakınlık uzaklıkla açıklanıp açıklanamayacağını sorar ve bu soruya -şimdilik- bir cevap ver(e)mez. ${ }^{10}$ Metinlerden yola çıkıldığında yyâdetnâme ve sıhhatnâmeler özelinde de bu sorunun kesin yanıtına ulaşılamamaktadır. Ancak Âsım'ın ziyaret edebileceği kadar yakınındaki hasta birine mektup göndermesi, Şeref Hanım'ın (ö. 1277/1860) uzaktaki dostuna mensur yerine "manzum" mektup yazması -ki bu mektup şairin divanında kayıtlıdır- bu tercihin her zaman mesafelerle ilgili olmadığını göstermektedir. Tespit edilen metinler çoğaldıkça bu soruya daha kesin bir cevap verme ihtimali artacaktır.

Peki türsel anlamda 1yâdetnâme ve sıhhatnâme arasında nasıl bir ilişki vardır? Münşeât mecmûaları ve/veya inşâ üzerine yapılan çalışmalarda kısaca değinilen ıyâdetnâmenin farklı tanımları yapılmıştır. Buna göre bazı araştırmacılar ıyâdetnâmeyi "ziyaret edilemeyen, rahatsızlığı işitilen dostların/hastaların hal ve hatırlarını sormak için yazılmış olan mektuplar" ${ }^{11}$ bazılarıysa "bir kimsenin hastalanıp tekrar iyileşmesi haberi üzerine yazılan, hastalıktan dolayı üzüntü, iyileşmeden dolayı sevinç bildiren mektuplar"12 şeklinde tanımlar. Dolayısıyla ikinci tanımda birinciden farklı olarak hastanın iyileşmesi mektubun yazılması için bir şart olarak ortaya konmuştur. Hasan Gültekin ise "herhangi bir hastalığa tutulmuş kişilerin bir an önce sağlığa kavuşmalarını dilemek veya hastalıktan kurtulmuş olan kişilerin sağlığa kavuşmalarından duyulan sevinci belirtmek amacıyla yazılan mektuplar" şeklinde tanımladığı ıyâdetnâmenin her iki amaçla da yazılabildiğini belirtmiş olur. ${ }^{13}$

10 Christine Woodhead, "The Gift of Letters: Correspondence Between Nergisi (d. 1634) and Veysi (d. 1627)”, Kitaplara Vakfedilen Bir Ömre Tuhfe: İsmail E. Erünsal'a Armağan, II, ed. Hatice Aynur, Bilgin Aydın, Mustafa Birol Ülker (İstanbul: Ülke Armağan, 2014), s. 979.

11 Ömer İnce, "İnşâ-i Merğûb ve İlm-i İnşẩda Müsta'mel Lügatler” (doktora tezi), Ege Üniversitesi SBE, 2007, s. 80; Çakır, "Türk Edebiyatında Mektup”, s. 130.

12 İ. Çetin Derdiyok, "XV. Yüzyıl Şāirlerinden Mesịhỉnin Gül-i Sad-berg’’” (doktora tezi), Çukurova Üniversitesi SBE, 1994, s. 89; Mustafa Kaşka, "Dîvân Edebiyatı'nda Münşe’ât Geleneği ve Hoca Neş'et’in Mektupları” (yüksek lisans tezi), Dokuz Eylül Üniversitesi Eğitim Bilimleri Enstitüsü, 2000, s. 25; Abdurrahman Daş, "Osmanlılarda Münşeât Geleneği, Hoca Sadeddin Efendi'nin Hayatı, Eserleri, Münşeâtı” (doktora tezi), Ankara Üniversitesi SBE, 2003, s. 47; Recep Gökçe, "Eski Türk Edebiyatında Mektup ve Bir Mecmû́a-i Münşeât” (yüksek lisans tezi), Erciyes Üniversitesi SBE, 2006, s. 17.

13 Hasan Gültekin, “Türk Edebiyatında İnşâ: Tarihî Gelişim-Kuram-Sözlük ve Metin” (doktora tezi), Hacettepe Üniversitesi SBE, 2007, s. 258. Burada Ömer Çakır’ın kapsayıcı bir tanım yapmasa da muhtevalarından bahsederken ıyâdetnâmelerin her iki durum için yazılabildiğine değindiğini belirtmek gerekir. Bkz. Çakır, "Türk Edebiyatında Mektup”, s. 130. 
Münşeât mecmûaları tarandığında Gültekin'in tanımında belirttiği gibi her iki durumu örnekleyen ıyâdetnâmelerle karşılaşılmaktadır. Örneğin Mesîhî, Gül-i Sad-berg'de bulunan iki ıyâdetnâmesini de ${ }^{14}$ muhataplarının şifa bulmasıyla duyduğu sevinci ifade etmek üzere kaleme almıştır. Son derece edebî bir şekilde yazılan bu mektuplarda Mesîhî öncelikle söz konusu kişilerin hastalığının kendisi ve/veya halk üzerindeki etkisini, perişanlıklarını sanatlı ifadelerle anlatır. Mektuplar iyileşme haberinin ulaşmasından dolayı hamd -ve birinde ayrıca muhataba dua- edilerek bitirilir. Şifa temennisinde bulunmak için yazılan yyâdetnâmelere ise Lâmiî Çelebi'nin kendisine gönderilen bir mektuba cevabi ${ }^{15}$ örnek gösterilebilir. Lâmiî bu mektubu almaktan duyduğu sevinci uzun uzun anlattıktan sonra "teb" yani hummaya yakalanmış olan mektup yazarı için dua eder. Ayet, hadis metinleri ve bir mısra ile zenginleştirilmiş bu dua bölümünde muhatabın doktor ve bilginlere ihtiyaç kalmadan iyileşmesi ve bundan sonra sıhhat ve afiyetle mutlu olması istenir.

Dolayısıyla araştırmacılar tarafından ıyâdetnâmenin üç temel özelliğinden biri olarak sayılmasına karşın ${ }^{16}$ hastanın iyileşmesinin ıyâdetnâme yazmak için elzem bir koşul olmadığı görülmektedir. Ayrıca Kırımlı Hafız Hüsâm (ö. on beşinci yüzyıl) ve Ahmed-i Dâî̀nin (ö. 824/1421'den sonra) Teressül, Yahyâ bin Mehmed el-Kâtib’in (ö. on beşinci yüzyıl) Menâhicül-İnşâ adlı mektup yazma kurallarıyla ilgili öncül eserlerinde yer alan örnek ryâdetnâmeler ${ }^{17}$ de hastalığa yakalanan kişiye

14 "Berây-1 '1yâdet" ve "Der-'1yâdet-i büzürgvârân" şeklinde isimlendirilen ve münşeâtta 73 ile 76. sırada bulunan bu mektupların metni için bkz. Derdiyok, "Mesịhị’nin Gül-i Sadberg'i”, s. 262-4 ve 267-9. Konya Mevlânâ Müzesi Ktp. 2254 numarada kayıtlı mecmûa içinde Mesîhînnin bazı mektupları bulunmaktadır. Bu mektuplar arasında 76 numaralı ıyâdetnâme de yer alır. Mecmûa üzerine yapılan çalışmada bu mektubun başlığı sehven "İbâdet-nâme" olarak okunmuştur. Bkz. Kezban Paksoy, "Mecmu'a-i Fevâid Konya Mevlana Müzesi Kütüphanesi 2254 (İnceleme-Metin-Tipkıbasım)” (yüksek lisans tezi), Erciyes Üniversitesi SBE, 2006, s. 42.

15 Münşeâtta 8. sırada bulunan ve "Ba'zı ekâbirün gönderdikleri mektûb-1 şerîfün cevâbı sûretidür ki mektûblarında hastalıkdan ve hevâdan şikeste olduklarından i'lâm itmişlerdür" şeklinde başlıklandırılan bu mektubun metni için bkz. Hüseyin Karaman, "Lamiî Çelebi'nin Münşeâtı" (yüksek lisans tezi), Afyon Kocatepe Üniversitesi SBE, 2001, s. 77-8. Lâmiîn nin bu mektubu asıl itibariyle bir cevapnâme olmakla birlikte bilhassa ikinci bölümü muhtevası bakımından ıyâdetnâme özelliği göstermektedir. Cevapnâmeler hakkında bkz. Derdiyok, "Mesīhị’nin Gül-i Sad-berg'i”, s. 82-3.

16 Derdiyok, "Mesịhịnnin Gül-i Sad-berg'i”, s. 88; Derdiyok, “Osmanlı Devrinde Mektup Yazma Geleneği”, Osmanlı, 1999, IX, 739.

17 Biri Farsça olmak üzere toplam dört tane olan bu mektupların metni (ve tercümesi) için 
üzüntü ve şifa dileklerinin iletilmesiyle sınırlandırılmıştır. ${ }^{18}$

Aynı türden bir tanım/kapsam problemi sıhhatnâmeler için de geçerli olmuştur. Bunların bazı kaynaklarda hastalanan birinin iyileşmesi "dileğiyle”, bazılarındaysa iyileşmesi "dolayısıyla” yazılan şiirler olarak tanımlanması Halûk Gökalp'i "Sıhhatnâmeler müjde şiirleri mi yoksa dua ve temenni şiirleri midir?" sorusunu sormaya yöneltmiştir. Neticede metinlerden yola çıkarak sıhhatnâmeyi "hem 'hastalanan kişinin iyileşmesinin tebrik edilmesi, müjdelenmesi' hem de 'muhatabın şifa bulması dileği, duası” olarak tanımlayan araştırmacı böylece türün daha kuşatıcı tanımını yapmıştır. ${ }^{19}$ Gökalp ayrıca sıhhatnâmelerin temel/esas amacının/ işlevinin hastalığın iyileşmesini kutlamak ve müjdelemek olduğunun altını çizerek şifa temennisi/duası içeren manzumelerin nadirliğini/istisnâ̂liğini vurgular. ${ }^{20} \mathrm{Bu}$ temel işlev meselesi yyâdetnâmeler ve yeni tespit edilmiş/edilecek sıhhatnâmeler de göz önüne alınarak yeniden düşünülmelidir. Şairlerin Gökalp’in de belirttiği üzere câize almak için müjdeli ve müspet ${ }^{21}$ bir olayı konu olarak seçmesi son derece doğaldır; ancak bu, türle ilgili bir durumdan ziyade şair ve yazarların tercihi ya da teamüllerle ilgili olmalıdır. Kaldı ki yukarıda belirtildiği üzere Teressül ve Menâhicül-İnşâ gibi teori kitaplarında 1yâdetnâmeler üzüntü ve şifa dilekleri/duası içeren mektuplar olarak yer almaktadır.

bkz. Kırımlu Hafız Hüsam, Teressül (Hacı Selimağa, Nurbanu No: 122/5)-İnceleme, Transkripsiyon, Çeviri, Açılamalar, Faksimile, haz. Şinasi Tekin ([Cambridge]: Harvard Üniversitesi Yakındoğu Dilleri ve Medeniyetleri Bölümü, 2008), s. 55-6 ve 99-100; Halil İbrahim Haksever, "Ahmed-i Dâînin Teressülü", Turkish Studies-International Periodical for the Languages, Literature and History of Turkish and Turkic, VI/1 (2011), s. 1272 ve Yahyâ bin Mehmed el-Kâtib, Menâhicü̉l-İnşâ (İnceleme-Metin), haz. Fahri Unan (Ankara: TTK, 2014), s. 94.

18 Bu eserlerden çok daha önce Mevlânâ Celâleddîn-i Rûmî (ö. 672/1273) tarafından kaleme alınan iki mektup da muhataba geçmiş olsun dilek ve dualarını içerir. Bkz. Mevlânâ Celâleddîn, Mektuplar, çev. ve haz. Abdülbâki Gölpınarlı (İstanbul: İnkılâp ve Aka, 1963), s. 178-9 ve 218-9. (Mevlânânın mektuplarının tematik tasnifi için bkz. Akalın, "Duacı Bir Baba”, s. 5-6.) Gölpınarlı Mevlânầnın mektuplarının hitaplarda teşrifat ve inşâ kaidelerine riayet etmediğini belirtir (s. XIII, XVI); ancak bu iki mektup Osmanlı döneminde kaleme alınan ıyâdetnâmelerle bazı açılardan benzer özelliklere sahiptir. Ayrıca Selçuklu inşâ kurallarıyla ilgili olarak bkz. Cevdet Yakupoğlu ve Namiq Musalı (haz.), Hasan b. Abdülmümin el-Hôŷ̀n nin Kaleminden Selçuklu İnşẩ Sanatı (Ankara: TTK, 2018).

19 Gökalp, "Divan Şiirinde Sıhhat-nâmeler", s. 104-9. Sıhhatnâmelerle ilgili yapılan tanımlama ve sınıflamalar hakkında yorum ve düşüncelerim için bkz. 35. ve 36. dipnotlar.

20 Gökalp, "Divan Şiirinde Sıhhat-nâmeler”, s. 109, ayrıca bkz. s. 106-7, 125.

21 Gökalp, "Divan Şiirinde Sihhat-nâmeler", s. 107. 
Bu noktada ıyâdetnâme ve duânâme ilişkisi de sorgulanmalıdır. Duânâme araştırmacılar tarafından "din ve devlet büyükleri için ana-baba için Tanrıdan iyi dilek ve temennîlerde bulunmak üzere yazılmış olan mektup", ${ }^{22}$ "yazılış amacı ve dolayısıyla muhtevası duâ olan mektup", 23 "belli bir kişinin iyiliğini istemek, ilerideki hayatında Allah'ın rızasını kazanması için yapılan duaların yer aldığı mektup", ${ }^{24}$ "muhataba dua amacıyla yazılan mektup" ${ }^{25}$ olarak tanımlanır. Bu tür mektuplarda münşîler muhataplarının ömr ü devletinin devamı veya artması, talihinin yaver gitmesi, düşman karşısında muzaffer olması, bayramının mübarek olması ve daha pek çok bayrama ulaşması, hastalığının iyileşmesi gibi konularda dua ederler. ${ }^{26}$ Dolayısıyla hastalıktan şifa bulma temennisi/duası için yazılan duânâmelerin yine aynı amaçla yazılan ıyâdetnâmelerle ilişkisi dikkat çekicidir. Örneğin bir vaiz ve müfessir olan Vanî Mehmed Efendi’nin (ö. 1096/1685) Edirne civarında avlanırken "mizâc-ı sa âdet-imtizâclarında birez ârıza-i hummâ" olan IV. Mehmed'e (salt. 1648-1687) gönderdiği mektubu duânâme olarak başlıklandırılmıştır. ${ }^{27}$ Mektup Padişah'ın hastalanmasından dolayı yazarın üzüntüsü ile şifa dileklerini içerir ve tıpkı sıhhatnâmelerde olduğu gibi muhatabına duayla son bulur. Yine bir sonraki duânâme başlıklı mektubunda ${ }^{28}$ Vanî Padişah'a "sıhhat ü selâmet-i 'âcil ü kâmil ve devlet ü 'âfiyet-i vâfir ü şâmil” duasının yanı sıra düşmana karşı muzaffer olma temennisinde bulunur. Dolayısıyla "Vanî̀nin bu mektupları (ve kuşkusuz içeriği bu şekilde olan bütün mektuplar) başlığına da dayanılarak sadece duânâme olarak mı görülmelidir, yoksa 1yâdetnâme özelliği gösterdiği söylenebilir ve bu başlık altında da değerlendirilebilir mi?” sorusu akla gelmektedir.

22 İnce, "İnşâ-i Merğûb”, s. 80.

23 Çakır, “Türk Edebiyatında Mektup”, s. 201.

24 Kaşka, "Dîvân Edebiyatı'nda Münşe’ât Geleneği”, s. 25; Gökçe, "Eski Türk Edebiyatında Mektup", s. 17.

25 Çakır, "Türk Edebiyatında Mektup”, s. 125.

26 Örnek duânâme metinleri için bkz. İnce, "İnşâ-i Merğûb”, s. 161; Hamza Konuk, "Vânî Mehmet Efendi'nin Münşêatı” (yüksek lisans tezi), Erciyes Üniversitesi SBE, 2001, s. 5862; Yûsuf Nâbî, Münşeât-ı Nâb̂̂ (Nâbînin Mektupları), haz. Adnan Oktay (İstanbul: Türkiye Yazma Eserler Kurumu Başkanlığı Yay., 2017), s. 180-1, 285-6, 380-1.

27 “Sultân Mehmed Han Hazretleri Edirne'den sayd ü şikâr kasdıyla yine Edirne havâlîsinde olan kasabât ü menzilgâhlara sefer-i humâyûn buyurduklarında mizâc-1 sa âdet-imtizâclarında birez ârıza-i hummâ dahı olmağla ol vakt Vanî Efendi tarafından rikâb-1 humâyûna yazılan duầ-nâmedir" bkz. Konuk, "Vânî Mehmet Efendi’nin Münşe’âtı", s. 58-9.

28 "Sefer-i humâyûn-1 sâbiku'z-zikrde Vanî Efendi tarafından rikâb-1 humâyûna irsâl olınan duầ-nâmeniñ sûretidir." Konuk, "Vânî Mehmet Efendi’nin Münşeâtı", s. 59-60. 
Münşeât veya mektup üzerine bugüne kadar yapılan çalışmalarda bir mektubun türüne karar vermenin ya da bir mektubu sadece bir türe dâhil etmenin oldukça zor olduğu dile getirilir. ${ }^{29}$ Bunun için temel kıstas mektubun ağırlıklı olarak içerdiği konu ve yazılış amacı kabul edilse de "türlerin tasnifinde çerçeveyi kesin çizgilerden ziyade birbirine geçişe müsaade eden kısa çizgilerle belirlemenin" yararlılığı vurgulanmıştır. ${ }^{30} \mathrm{Bu}$ nedenle araştırmacılar mektupların, başlıklarında belirtilen türlerin yanı sıra başka türlere uygun özellikler gösterebileceğini de belirtmiş ve bunun bir hatadan ziyade metne bakış açısıyla ilgili olduğunu söylemişlerdir. ${ }^{31}$ Dolayısıyla daha çok manevî derinliği olduğuna inanılan şeyh, vaiz gibi din adamlarınca devletin ileri gelenlerine yazıldığı söylenen ${ }^{32}$ ve dua kısmının mektubun büyük bölümünü oluşturduğu duânâmelerin muhatabının hastalıktan iyileşmesi dileğini/duasını içerenlerinin bir yönüyle ıyâdetnâme olduğunu ve bu tür mektupların da ıyâdetnâmelerin özellikleri açısından incelenebileceğini söylemek mümkün görünmektedir.

Dua içerikli mektupların yanı sıra mesnevi şeklinde müstakilen yazılmış ya da divanlarda çeşitli nazım şekilleriyle söylenmiş manzum duânâmeler de bulunmaktadır. "Daha çok başkası için edilen duaların işlendiği manzumeler" olan duânâmelerde "özellikle padişahlar için ömürlerinin ve saltanatının uzun, muzafferiyetlerinin daimî olması" için duada bulunulur. ${ }^{33}$ Bunların sıhhatnâmelerle ilişkisi üzerinde de durmak gerekir zira şairler bu tür metinlerde muhataplarının hastalıktan iyileşmesi duasında da bulunmuşlardır. Örneğin Şeref Hanım’ın divanında bulunan "yâ Rab” redifli gazel (G19) ${ }^{34}$ muhatabın şifa bulması ve böylece

29 Yûsuf Nâbî, Münşeât-ı Nâbî, s. 120; Çakır, “Türk Edebiyatında Mektup”, s. 106.

30 Çakır, "Türk Edebiyatında Mektup”, s. 106.

31 Yûsuf Nâbî, Münşeât-ı Nâbî, s. 120.

32 Çakır, "Türk Edebiyatında Mektup”, s. 125.

33 Sebahat Deniz, "Kadızâde Mehmed İlmînnin Sultan IV. Murad İçin Yazdığı Manzum Duânâme’si”, Divan Edebiyatı Araştırmaları Dergisi, 1 (2008), s. 16.

34 Divanların künyeleri kaynakçada verildi. Burada şunu da belirtmekte fayda var: Şairin divanında aynı redifle yazılmış dört gazel daha (G8, G9, G10, G11) bulunmaktadır. Şeref Hanım 8. gazelin 3. beytinde hasta olduğunu belirtip Allah'tan yardım ve şifa beklediğini söylese de gazelin diğer beyitlerinden bunun gerçek anlamda bir hastalık olmadığı, mecazî bir hastalıktan (ayrılık, günahkârlık vb.) bahsettiği anlaşılmaktadır. Dolayısıyla bu gazeli şairin kendisi için yazdığı bir sıhhatnâme olarak görmek yanlış olur. Benzer bir durum "Allâh'ım” redifli gazelde (G145) de vardır. Şairin "yâ Resûlallâh” redifli naatlarından birinde (G226) "illet-i sadr” ile hasta olduğunu söyleyip Hz. Peygamber'den şifa dilemesi de aynı şekilde değerlendirilmelidir. Bir başka kadın şair Leylâ Hanım (ö. 1264/1848) da 
şairin kendisini görebilmesi duasını içerir. Gökalp’in -diğer birkaç manzumeyle birlikte- "dua içerikli sıhhatnâme" ve "dua bölümünü öne çıkaran sıhhatnâme" olarak nitelendirdiğ $i^{35}$ gazelin muhatabın şifa bulması için yazılmış bir duânâme olduğu da iddia edilebilir. Bu durumda gazelin -mektuplarda olduğu gibi- hem bir duânâme hem de sıhhatnâme örneği olduğunu söylemek yanlış olmayacaktır. Seyyid Vehbî̀nin (ö. 1149/1736) divanında bulunan ve "Sıhhat-nâme berây-1 Sultân Ahmed Han-1 Sâlis" başlıklı 7 beyitlik mesnevide ise (K75) ise çeşitli şekillerde övülen Padişah'a "cihan gülşeninin revnakı olması, haşre dek çerağının sönmemesi, çocuklarıyla mutlu şekilde yaşaması, daima gülmesi” için dualar edilir.

divanındaki bir gazelinde (G107) manevî hastalığını arz ettiği şeyhi İsyânî Baba’dan himmet beklentisini dile getirmiştir. [Leylâ Hanım diğer bazı şiirlerinde de (G104, G121, Kt1) kendini (manevî) "hasta" olarak nitelemiş, Şeref Hanım gibi Allah'tan, Hz. Peygamber'den ve ayrıca şeyhinden şifa talep etmiştir.] Divanın nüshalarından birinde İsyânî Baba’nın Leylâ Hanım’ın bu gazeline cevabı da kaydedilmiştir (Metin için neşirde söz konusu gazelle ilgili dipnota bkz.) İsyânî Baba "İlâhî izzetiń hakkı benim Leylầma sıhhat vir / Süründürme hakîm sensin sen ol derdine tâkat vir” şeklinde başladığı 5 beyitlik gazelinde Allah'ın rahmet edip Leylâ Hanım'ın günahlarını affetmesi, ona gayret vermesi, gönül fethini müyesser kılması için dua eder. Dolayısıyla müridinin tarikat yolunda karşılaştığı zorlukları aşması için Şeyh'in bir duânâme kaleme aldığı anlaşılıyor. Fizikî anlamda bir hastalık nedeniyle söylenmeyen bu gazeli de bir sıhhatnâme olarak değerlendirmek doğru olmasa gerek. Bu arada İsyânî Baba hakkında kaynaklarda bilgiye ulaşılamamaktadır. Tuhfe-i Nâilì̀de bu söylendikten sonra divanının yeri belirtilir. Bkz. Fatma Özdemir, "Tuhfe-i Nâilî Metin ve Muhtevâ II. Cilt s. 468-734” (yüksek lisans tezi), Cumhuriyet Üniversitesi SBE, 2011, s. 518. Millet Ktp. AE Manzum no. 300'de Gazeliyyât-ı İsyâñ̂ ismiyle kayıtlı bulunan ve daha çok bir divançe niteliğindeki eserde bu gazel bulunmuyor.

35 Gökalp, "Divan Şiirinde Sıhhat-nâmeler", s. 113. Kanaatimce "dua içerikli/içeren sıhhatnâme” tabiri iyileşme müjdesini ve bundan duyulan sevinci ele alan sıhhatnâmelerde de geniş yer kaplayan ve muhatabın "saltanat ve/veya ömrünün devamlı/uzun olması, tekrar hastalanmaması, hiçbir zaman gam çekmemesi, her zaman mutlu ve huzurlu olması" için yapılan duaları görmezden geldiğinden yanlış bir tabir. Ayrıca iyileşmeyi tebrik dolayısıyla yazılan sıhhatnâmelerden diğerlerini ayırmak için kullanıldığı anlaşılan "dua içerikli/ dua bölümünü öne çıkaran/tamamen dua içeren sıhhatnâmeler” tabirlerinin muhataba şifa dileklerini iletmek amacıyla yazılan ama duânâme özelliği taşımayan Ahmed Paşa (ö. 902/1496-7) ve Zaîfìnin (ö. 964/1557) manzumeleri için kullanılamayacağı söylenebilir ki ilgili makalede de bu sıhhatnâmeler herhangi bir kategori altında ele alınmıyor. Dolayısıyla iyileşmeyi tebrik/müjde içerikli sıhhatnâmelerin karşısında yer alan manzumeleri "dua içerenler" vb. şeklinde değil, ıyâdetnâmelerde olduğu gibi "hastanın hâlini hatırını soran ve şifa bulması temennisi/duası içeren" sıhhatnâmeler olarak nitelemek daha doğru olabilir. Ancak aşağıda değinileceği gibi bu isimlendirme de türün bütün örneklerini kapsamamakta. 
Padişah'ın hastalığı ya da iyileşmesine dair herhangi bir bilgi hatta kelime barındırmayan bu manzume -yanlış başlıklandırılmadıysa ya da baştan eksik değilsebir yandan sıhhatnâmeler ve manzum duânâmeler arasındaki ilişkiyi gösterirken diğer yandan "dua içeren sıhhatnâmeler"in her zaman doğrudan şifa temennisi için yazılmadığını, dolayısıyla sıhhatnâmelerle ilgili tanımın dışında kalan istisnaî metinlerin varlığını gösterir. Zira bu metin doğrudan ne "hastalığın iyileşmesini tebrik" ne de "muhatabın şifa bulma duası/temennisi” dir. Şair hastalık ve iyileşme sürecine hiç gönderme yapmadan Padişah' in huzurlu ve mutlu bir hayat sürmesini diler ki metnin altında bunun sağlıkla mümkün olduğu/olacağı iması olduğu anlaşılmaktadır. ${ }^{36}$ Ancak bütün sıhhatnâmeler içinde hastalık ya da iyileşme sürecinden birkaç kelimeyle de olsa bahsetmeyen -şimdilik- tek örnek olmasından dolayı mesnevinin yanlış isimlendirilme ya da eksik olma ihtimali de göz önünde bulundurulmalıdır. ${ }^{37}$

36 Gökalp, sehven kaside-beççe olduğunu belirttiği (s. 116) ve "tamamen dua içeren sıhhatnâme" (s. 117) ile "sıhhat-nâme başlıklı dua manzumesi" (s. 113) olarak nitelediği bu mesnevinin Şeref Hanım’n gazeli (G19) ve makalenin aşağıdaki bölümünde bahsedilecek iki mesnevisiyle (M4, M5) benzer özellikler içerdiğini söyler (Gökalp, "Divan Şiirinde Sıhhat-nâmeler”, s. 113). Ancak Vehbînnin mesnevisi ve Şeref Hanım’ın gazeli duânâme olmaları bakımından benzeşseler de işlevsel olarak farklılık arz edebilir. Şöyle ki gazel hususiyetle muhatabın iyileşmesi duası içerirken, mesnevi -hakikaten bir sıhhatnâmeyse- iyileşmeden sonra da yazılmış olabilir. Bu durumda Vehbî iyileşme üzerine yazılan sıhhatnâmelerde olduğu gibi muhatabın "bundan sonra" ve "daima" mutlu, huzurlu olması için dua etmiştir. Dolayısıyla bu mesnevi sıhhatnâmelerle ilgili yapılan tanım ve tasniflerin dışında kalmaktadır. Bu durumda sıhhatnâme geleneğinde bazı istisnaî/alternatif metinlerle de karşılaşlabileceği anlaşılmaktadır. Ancak her ne amaçla yazılırsa yazılsın bütün bu metinlerin ortak özelliğinin şiir yazma/sunma yoluyla "muhataba geçmiş olsun demek" ve "kulluğunu/ dostluğunu sunmak/ifade etmek” olduğunun altı çizilmelidir. Öte yandan Şeref Hanım’ın mesnevi biçimindeki manzum mektupları da şairin gazelinden ve Vehbînnin manzumesinden "tamamen dua içerikli" olmamaları açısından ayrılır. Şeref Hanım bu mektuplarda muhatabına şifa temennisinde bulunsa da farklı konulara da değinir. Bu durumda bu mesnevilerin -Zaîfîn nin mesnevisi gibi- manzum mektup olmasının etkisi vardır.

37 Seyyid Vehbî Divanı'nın Topkapı Sarayı Müzesi Ktp. E.H. 1640/1'de kayıtlı nüshasında herhangi bir boşluk yoksa da Süleymaniye Kütüphanesi'nde bulunan nüshalarının birinde (Mihrişah Sultan no. 369, vr. 88a-89b) 7 beyitlik bu metnin hemen öncesinde 2-3 sayfalık boşluk bulunması metnin bir manzumenin -ki bunun sıhhatnâme türü dışında bir manzume olması da mümkün- dua bölümü olduğu görüşünü destekler niteliktedir. En azından böyle bir ihtimali akla getirmektedir. Yine aynı kütüphanede Esad Efendi no. 2714'te bulunan nüshada da metnin hemen öncesinde yaklaşı iki sayfalık bir boşluk bulunmakla 
Burada münşeâtların dışında divan ve mesnevilerde yer alan "manzum" mektuplardan da bahsetmek gerekir. Örneğin Zaîfî̀nin (ö. 964/1557) Sergüzeştnâme’sinde "Der-beyân-1 kıssa-i 'Işkî vü Ma'şûk" adlı hikâye içerisinde 'Işkî sevgilisi Ma'şûk’a şifa dileklerini iletmek için manzum bir mektup yazar. Eserde bu mektup içeriği veya türü belirtilecek şekilde "Sûret-i '1yâdet-nâme" olarak başlıklandırılmıştır. ${ }^{38}$ Yine Şeref Hanım'ın divanında "Sûret-i mektûb” şeklinde isimlendirilen ve şairin dost veya dostlarının hastalanması üzerine şifa temennilerini ileten iki mesnevisi (M4 ve M5) bulunmaktadır. Her üç metnin de araştırmacılar tarafından ıyâdetnâme ${ }^{39}$ ve sıhhatnâme ${ }^{40}$ olarak nitelendirilmesi dikkat çekicidir. Öte yandan Ahmed Paşa’nın (ö. 902/1496-7) divanında bulunan kasidenin (K32) "Der-'1yâdet-i şâh-1 devrân”, Nevres-i Kadîm'in münşeâtında bulunan mektubun "İstanbul'dan ma'zûl Şeyhü’l-İslâm Halîl Efendi-zâde 'Abdu'rrahîm Monlâ’ya Burusa'dan irsâl olunan sıhhat-nâme sûretidür" ${ }^{41}$ şeklinde başlıklandırılması ortak/benzer işlev, söylem ve kurguya sahip bu "tür" metinlerin içinde üretildikleri gelenekte de birbirlerinden farklı algılanmadıklarının bir göstergesidir. ${ }^{42}$

beraber başlıkla bu 7 beyitlik mesnevinin sıhhatnâme olduğu belirtilmiştir (bkz. 98b-99b). Bu son nüshanın 99. varağının sehven 89 olarak numaralandırıldığını da belirtmek gerekir. 38 Bu metnin manzum bir mektup olduğuna değinmeyen Gökalp bu isimlendirmeyi Ahmed Paşa'nın kasidesinin de başlığından yola çıkarak "türün ilk örneklerinde 'ıyâdet' başlı̆̆ının daha yaygın olduğu” şeklinde yorumlar (Gökalp, "Divan Şiirinde Sıhhat-nâmeler”, s. 114). Ancak başlığın, bir mektup olan metnin içeriğini/türünü belirttiği anlaşılmaktadır. Mesnevilerde yer alan manzum mektuplarla ilgili bkz. Dilek Batislam, "Mesnevilerde Mektup Tarzı Anlatım”, İlmî Araştırmalar, 13 (2002), s. 17-34.

39 Elif Aydın, "Divanlardaki Manzum Mektuplar” (yüksek lisans tezi), Çukurova Üniversitesi SBE, 2007, s. 42; Vildan Serdaroğlu Coşkun, "Sergüzeştüm Güzel Hikâyetdür" Zaîfînin Sergüzeştnâme’si (İstanbul: İSAM, 2013), s. 79.

40 Gökalp, "Divan Şiirinde Sıhhat-nâmeler", s. 110, 113.

41 Fatih Elçi, "Nevres-i Kadîm’in Münşeâtı (İnceleme-Metin)”, (doktora tezi), Adıyaman Üniversitesi SBE, 2017, s. 247.

42 Tür kavramının özellikle klasik edebiyat söz konusu olduğunda tartışmalı olduğu malumdur. Yapılan sınıflamaların kısıtlayıcı, eksik, hatta hatalı olduğu pek çok araştırmada dile getirilmiştir. Örneğin Selim S. Kuru bu konuda şöyle söylemektedir:

Anadolu'da üretilen Türkçe edebiyat ürünleri, genelde önce biçim, sonra konu temel alınarak yapılan türsel sınıflama yoluyla değerlendirilmektedir. Bugüne kadar tür tanımları genelde temel nazım biçimleri üzerinden konulara göre yapıldı ve nesir eserler arasında dilsel özellikleri dışında herhangi ciddi bir sınıflandırma gözetilmedi. (...) Kısacası biçime dayalı tür sınıflandırması bir 
Son olarak iyâdetnâmeler (ve sıhhatnâmeler) ile hususî mektuplar gibi münşeât mecmûalarında toplanan telhislerin ilişkisine değinilmelidir. Osmanlı resmî belgeleri ile kasideler arasındaki benzerlik daha önce dile getirilmiştir. ${ }^{43}$

yandan çeşitli hallerin değişik nazım biçimleri ve nesir nazım karışık eserlerdeki yayılımını, öte yandan nazım biçimlerinin ya da belli başlı konularda yazılan eserlerin geçirdikleri tarihsel ve düşünsel dönüşümleri görmemizi engelliyor. Bu durumda belki de tür/biçim temelli sınıflandırmaları bir kenara bırakmalı ve hallere bakmalıyız." [Selim S. Kuru, "Mesnevî Biçiminde Aşk Hali: Birinci Tekil Şahıs Anlatılar Olarak Fürkat-nâme, Heves-nâme Üzerinden Bir Değerlendirme", Eski Türk Edebiyatı Çalışmaları IV: Nazımdan Nesire Edebî Türler (25 Nisan 2008 Bildiriler), haz. Hatice Aynur vd. (İstanbul: Turkuaz, 2009), s. 170-1].

Fatih Altuğ ise türü "nispeten sabit metinsel uzlaşımlar/teamüller kümesi” olarak tanımlar ve bu teamüllerin, tarih ve toplum dışı bir yerde oluşmadığını, içinde bulunulan toplumun makbul saydığı çeşitli etkinliklerle ilişkili olduğunu, bu etkinlikler tarafından oluşturulurken aynı zamanda bu etkinlikleri oluşturduğunu söyler. Dolayısıyla "türler, yalnızca belirli metin çeşitlerini ima etmezler, metinleri üretmenin, dolaşıma sokmanın ve alımlamanın çoğul süreçlerini de ima ederler." Fatih Altuğ, "Başka Türlü Bir Yaklaşım Mümkün mü?”, Eski Türk Edebiyatı Çalısmaları IV: Nazımdan Nesire Edebî Türler (25 Nisan 2008 Bildiriler), haz. Hatice Aynur vd. (İstanbul: Turkuaz, 2009), s. 35. Bir edebiyat türünün belirli metinleri, dolaşım biçimlerini, toplumsal pratikleri bir yasa etrafında tedvin ettiğini belirten Altuğ bir türü çözümlerken hangi tür metinleri kendi yasası altında topladığına, hangi tür metinleri dışladığına, bu esnada hangi toplumsal pratiklerle bağlantılı olduğuna, kendisini işleten öznelere hangi imkânları açıp hangilerini kapattığına bakmak gerektiğini belirtir (s. 40-1). Altuğ yeni tür kuramlarında da dikkatin metinsel biçimlerden tematik içerik, toplumsal bağlam, tarihsel yörüngelere vb. yöneldiğini; türlerin söylemsel özellikler, tematik içerik ve belagat pratiklerinin belli bir dengede karara varmasıyla, istikrara kavuşmasıyla yapılandırıldığını aktarmaktadır (s. 39). Kuru ve Altuğ’un salt konu ya da biçime bağlı ve tarihselliği/bağlamı dışlayıcı tür tanım ve sınıflandırmalarına karşı çıkan bu yaklaşımlarına dayanarak şairlerin memdûha ulaşmak için hastanın hâlini hatırını sorma sünneti/âdeti üzerine bina ederek ürettikleri ıyâdetnâme ve sıhhatnâmelerin aynı türe ait ürünler/metinler olduğu söylenemez mi, sorusu sorulabilir. Bu metinler faklı metinsel biçimlerde (nazım ve nesir) yazılsalar da benzer içerik ve yapı özelliklerini, söyleyiş biçimlerini kullanmışlardır. Başka bir deyişle günlük yaşamdaki hastalar ve sağlığına henüz kavuşmuş kişilere geçmiş olsun deme pratiğiyle ilişkili bu metinler benzer söylem, işlev ve kurguya sahiptirler. Dolayısıyla bu metinlerin belli bir "yasa" çerçevesinde üretildikleri anlaşılmaktadır.

43 Ebubekir Şahin, "Medh ve Hamd Kavramları Çerçevesinde Medhiye Üslûbu Üzerine”, Eski Türk Edebiyatı Çalışmaları VIII: Kasîdeye Medhiye: Biçime, İ̧̧leve ve Muhtevaya Dair Tespitler, haz. Hatice Aynur vd. (İstanbul: Klasik, 2013), s. 345-9. 
Aynı amaçla yazılmış manzum ve mensur metinlerin birlikte ele alınması gerektiği düşünüldüğünde bu tespiti "Osmanlı resmî belgeleri ile edebî/tarihî metinleri arasındaki benzerlik" olarak tashih etmek mümkündür. "Osmanlı bürokrasisinde sadrazamın padişaha türlü meselelerle ilgili yolladığı tezkere veya arz" "44 olarak tanımlanan telhis, mektup gibi inşâ geleneğinin önemli bir kolunu oluşturmaktadır. ${ }^{45}$ Memuriyete tayin, diplomatik konular, savaş vb. çeşitli devlet işlerinin yanı sıra belirli ve mübarek günlerin tebriki, padişahın sıhhatiyle alakalı gelişmeler, taziyede bulunma gibi konularda da telhisler yazılmaktaydı. ${ }^{46}$ Örneğin on sekizinci yüzyıla ait bir mecmûada yer alan telhis, padişahın ayağında çıkan çıban sebebiyle kaleme alınmıştır. ${ }^{47}$ Kim olduğu tespit edilemeyen sadrazam padişaha hastalıklardan korunmuş bir şekilde/afiyetle saltanat tahtında daim olması duasını ettikten sonra hastalığından duyduğu üzüntüyü ve iyileşmesi için dua ettiğini dile getirir. Daha sonra -iyileşmenin habercisi olan- çıbanın özünün çıktığı müjdesiyle hamd ettiğini ve bu müjdenin arz-1 ubudiyet (yani söz konusu telhisi yazması) için vesile olduğunu belirtir. Telhis padişahın daima sağlıklı olması duasıyla son bulur. Yine aynı mecmûada bulunan "Vücûd-1 humâyûnda zuhûr iden 'illetiń def i da'avâtı zımnında telhîs" ${ }^{4}$ başlıklı belge padişaha sıhhat için edilen duayla başlar. Sadrazam sultanın hastalığından kaynaklanan acı ve kederinin iyileşmeyle sonlanması ve bu teselliyle şükür secdesi yapmasından bahseder. Yapılan duanın ardından elemin definin "teşekkürü" ve sadrazamın kulluğunun ifadesi için söz konusu telhisin yazıldığı söylenir. ${ }^{49}$ Dolayısıyla padişahla sadrazam arasında resmî

44 Pál Fodor, "Telhis", DİA, 2011, XL, 401-2.

45 Bkz. Mübahat S. Kütükoğlu, Osmanlı Belgelerinin Dili (Diplomatik) (İstanbul: Kubbealtı Neşriyâtı, 1994), s. 6; Cengiz Orhonlu, "Telhîs", İA, 1979, XII/I, 149; Mustafa Uzun, "İnşâ/Türk Edebiyatı", DİA, 2000, XXII, 338.

46 Fodor, “Telhis”, s. 403; Kütükoğlu, Osmanlı Belgelerinin Dili, s. 206; H. Abdülkadir Özel, "Koca Râgıb Mehmed Paşa’nın Münşe’ât ve Telhîsâtı (Değerlendirme-Metin)” (yüksek lisans tezi), Mimar Sinan Güzel Sanatlar Üniversitesi SBE, 2014, s. XVI.

47 "Şevketlü efendimiz hazretleriniń mübârek kadem-i sa âdet-tev'emlerinde çıan zuhûr itdiğinde yazılan telhîs” başlı̆̆ına sahip belgenin metni için bkz. Sevda Yıldız, "18. Yüzyıla Ait Telhis, Takrir ve Buyuruldu Mecmuası” (yüksek lisans tezi), Bilecik Şeyh Edebali Üniversitesi SBE, 2018, s. 113-4.

48 Yıldız, "Telhis, Takrir ve Buyuruldu Mecmuası”, s. 114-5.

49 Benzer örnekler için bkz. Yıldız, "Telhis, Takrir ve Buyuruldu Mecmuası”, s. 115-8. Burada Koca Râgıb Paşa’nın (ö. 1176/1763) münşeâtında yer alan "Tebrîk-i hengâm-1 tedâvî-i tab'-1 humâyûn ve 'arz u takdîm olınan hedâyâ-yı 'ubûdiyyet-meşhûn kabûli recâsını hâvî yazılan telhîsdür” (Özel, "Koca Râgıb Mehmed Paşa’nın Münşểe ve Telhîsâtı”, s. 142-3) başlıklı belgeden de bahsetmek gerekir. Bu telhis padişahın hastalığı atlatmak amacıyla 
bir yazışma türü olan telhislerin padişahın hastalığından duyulan üzüntüyü ve iyileşmesinden duyulan sevinci anlatan örneklerinin yazılma sebebi dolayısıyla hususî mektup türü olan yyâdetnâmelerle benzeştiğini söylemek yanlış olmayacaktır. Ayrıca bu metinler yeri geldiğinde dipnotlarda belirtileceği gibi muhteva ve söyleyiş özellikleri bakımından da ıyâdetnâmelerle ortak özelliklere sahiptirler.

\section{Iyâdetnâme ve Sıhhatnâmelerin Karşılaştırmalı Özellikleri}

Iyâdetnâme ve sıhhatnâmelerin muhataplarının her zaman "hasta" kişinin kendisi olmadığı görülür. Cevrînnin (ö. 1065/1654) kendi ifâkati için yazdığı sıhhatnâmede (K55) muhatap kendini iyileştiren hekim Hacı Mehmed'dir. Gökalp manzumenin bu iki yönüyle diğer sıhhatnâmelerden ayrıldığının altını çizer. ${ }^{50}$

şerbet içmesinden duyulan sevinci ve iyileşmesi için edilen duaları iletmek üzere yazılmıştır. Koca Râgıb Paşa, hasta padişahın sağlığına kavuşarak saltanat tahtında daimî olması duasını edip iyileşmek amacıyla şerbet içmesini arz-ı ubudiyet görevi için bir vesile gördüğünü ifade eder. Daha sonra bu tedbir yani şerbet içme vesilesi ile Allah'tan şifa duasını tekrar eder. Paşa padişahın bahar aylarında "tedâbir-i hıfz-ı sıhhat" için şerbet içmesine de telhisler yazmıştır. Metinler için bkz. Özel, "Koca Râgıb Mehmed Paşa'nın Münşe’ât ve Telhîsâtı”, s. 100-1 ve 121-2) Bunlar ve padişahın kan aldırmasını (fasd) tebrik amacıyla yazılan telhis (bkz. Özel, "Koca Râgıb Mehmed Paşa’nın Münşeât ve Telhîsâtı”, s. 119-20) -bu tedbirlerin hastalıktan korunmak ya da kurtulmak için uygulanmasından dolayı- bol bol sıhhat duası içermeleri bakımından ıyâdetnâmelere benzeseler de yazılma amaçları (iyileşme/sağlığı koruma için şerbet içmeyi ve kan aldırmayı tebrik) bakımından daha özel metinlerdir. Son olarak Râgıb Paşa’nın padişahın hastalığı üzerine gönderdiği telhis ile hediyenin kabulüne dair hatt-1 humâyûna teşekkürünü içeren telhisi, bazı nüshalarda "Mizâc-1 humâyûna bir 'illet târî oldığı istimâ‘ olındukda yazılan telhîs" şeklinde yanlış başlıklandırılmıştır. Bu telhis padişahın hastalığıyla ilgili doğrudan bir dua ve dileği ya da iyileşmesiyle ilgili sevinci içermemektedir. Metin için bkz. Özel, "Koca Râgıb Mehmed Paşa’nın Münşeât ve Telhîsâtı", s. 126-7; Gültekin, "Türk Edebiyatında İnşâ”, s. 412-3.

50 Gökalp, "Divan Şiirinde Sıhhat-nâmeler”, s. 108, 118. "Remedden halâs oldukda dinmişdür" başlıklı manzumenin ilk beytinde iyileşmesine hamd eden Cevrî sonrasında Allah'ın Hacı Mehmed'i kendisinin şifasına sebep/vesile eylediğini anlatır. Bundan sonra hekimin övgüsüne geçer ve hizmetinin mükâfatına kâdir olmadığını, elinden ancak dua etmek geldiğini söyler. Manzumesini hekime sıhhatli uzun ömür ve ukbâda cennet makamı dileyerek bitirir. Dolayısıyla bu şiir hastalanmış ya da sıhhate kavuşmuş muhataba geçmiş olsun dileklerini iletmek için yazılmaması açısından da diğer sıhhatnâmelerden ayrılır. Anlaşılan Cevrî manzumesini muhatabından herhangi bir beklentiyle kaleme almamış, bu yolla Hacı Mehmed'e olan vefa borcunu ödemek ve ona teşekkür etmek istemiştir. Şairlerin kendi hastalıklarından bahsettikleri başka metinlerin tespitiyle bunların sıhhatnâme literatürü içindeki farklı konumu tartışılıp daha kesin yargılara ulaşılabilecektir. 
Bu şekilde bir muhatap farklılı̆̆ı Vanî Efendi’in IV. Mehmed hastalandığında hâlinden haber almak için Silahdar Hüseyin Ağa'ya yazdığı mektupta ${ }^{51}$ da görülür. Hastalıktan duyulan üzüntünün ve halkın Sultan'ın sağlığına kavuşması için gece gündüz durmadan dua ettiğinin belirtildiği mektupta Vanî şifa dileğini ilettikten sonra Hüseyin Ağa'ya IV. Mehmed'in hâlini, hastalığının hafifleyip hafiflemediğini sorar. Muhteva özellikleri bakımından yyâdetnâme özelliği gösteren bu mektup ıyâdetnâmelerde muhatabın her zaman hasta kişi olmadığını, çevresindekilere de bu tür mektuplar yazılabildiğini göstermesi bakımından önemlidir.

Muhatap kim olursa olsun hem ıyâdetnâmeler hem sıhhatnâmeler Çetin Derdiyok'un ıyâdetnâmelerin özellikleri arasında saydığ ${ }^{52}$ ve aslında pek çok tür -ve telhisler- için de geçerli olduğu gibi genellikle "rütbece küçük olanlar tarafından, rütbece daha büyük kimselere yazılır.” Bu durum ıyâdetnâmelerin bir diğer özelliği olarak gösterilen "sevgi ve bağlılık duygusu bildirme" 53 ile de alakalıdır. Sanatçılar gerek ıyâdetnâmeler gerekse sıhhatnâmeler yoluyla ihsan beklentileri olan kişilere ulaşıp onlarla aralarındaki bağı kuvvetlendirmeye çalışmaktadırlar. Böylece kendilerini tanıtmak, göstermek, hatırlatmak ya da özellikle bu kişilerin maiyetinde iseler kendilerinden beklenilen şekilde davranmak için uğraşmaktadırlar. Vanî Efendi’nin IV. Mehmed'e, Mesîhî̀nin "büzürgvârân”a, Lâmiî̀nin "ekâbir"e, Okçuzâde Mehmed Şâhînin (ö. 1039/1630) "bir sâhib-mekremet"e ${ }^{54}$ yazdığı mektuplar ile Nedîm (ö. 1143/1730), Kâmî (ö. 1136/1724), Seyyid Vehbî gibi şairlerin III. Ahmed'e yazdığı manzumeler bu şekilde değerlendirilebilir. Öte yandan Derdiyok yakın dostlar arasında da ıyâdetnâme yazılabildiğini söyler ki aynı durum sıhhatnâmeler için de geçerlidir. Şeref Hanım'ın manzum mektupları bu şekilde kaleme alınmıştır. Nâbî̀nin "himaye ettiklerinden biri olup sonradan sadrazamlığa kadar yükselen”55 Râmî Mehmed Paşa’ya (ö. 1119/1708) yazdı̆̆ı mektupların bu iki durumu birden örneklediğini söylemek mümkündür. Zira

51 "Sultân Mehmed Han Hazretleriniñ mizâc-1 humâyûnlarında ârıza-i hummâ nümâyân oldukda istihbâr-1 keyfiyyet-i tab'-1 'âlîlerin mütezammın tezkiredir ki silâh-dâr-1 şehriyâr Hüseyin Ağa’ya Vanî Efendi tarafından irsâl olınmışdur” başlıklı bu mektubun metni için bkz. Konuk, "Vânî Mehmet Efendi'nin Münşeâtı", s. 72.

52 Derdiyok, "Mesịhị’nin Gül-i Sad-berg'i”, s. 88; Derdiyok, "Mektup Yazma Geleneği”, s. 739.

53 Derdiyok, “Mesīịīnin Gül-i Sad-berg'i”, s. 89.

54 "Sûret-i mektûbdur ki tehniyye-i sıhhat içün bir sâhib-mekremete ketâib-i efânîn-i kitâbet tektîb ve mukaddimât-1 sadâkât tertîb olunmış idi” başlıklı mektubun metni için bkz. Okçuzâde Mehmed Şâhî, Münşe’ât, Süleymaniye Ktp. Esad Efendi no. 3294, vr. 19b-21a. 55 Abdülkadir Karahan, "Nâbî”, DİA, 2006, XXXII, 258. 
Nâbî kendinden üst makamda olan Paşa'ya pek çok mektup yazarak bağlılı̆̆ını bildirmiş, ama aynı zamanda aralarındaki yakın ilişkiden dolayı sık sık "devletlü, 'inâyetlü, semâhatlü, sa âdetlü oğlum, nûr-1 dîdem, efendi oğlum, efendi hazretleri” şeklinde hitap ettiği Paşa karşısında kendini "peder-i müştâk, peder-i senâver” olarak nitelemiştir. Münşî ıyâdetnâmesinde ${ }^{56}$ de hummaya tutulan Paşa’nın afiyette olduğu haberiyle yaşadığı sevinci dile getirirken hasta hasta sefer yapmasına da sitem etmektedir.

Bağlılığ 1 bildirme ve hami ile aradaki bağ kuvvetlendirme arzusu -aslında pek çok mektup türünde olduğu gibi- 1yâdetnâmelerin özellikle elkâb ve ibtidâ bölümlerinde hasta olan/şifa bulan muhatabın övgüsünün yapılmasına neden olmaktadır. ${ }^{57}$ Örneğin Vanî Efendi, hummaya yakalanan IV. Mehmed'e yazdığı mektuba şöyle başlar:

Sâye-i İlâh nâzır-1 'ibâdu'llâh nâsır-1 'adl ü dâd melek-sîret ü hoceste-nihâd âmme-i müslimîniñ dîdelerine nûr ve kâffe-i muvahhidîniń kalblerine surûr min-'indi'llâh muzaffer u mansûr ve her tarafda a'dâsı müzellel ü makhûr râfi'-i elviye-i dîn-i mübîn ve kâmi'-i kefere-i müşrikîn şehriyâr-1 heft-kişver ve tâcidâr-1 bahr u ber a'ni's-sultâne'l-a'zame'l-efhame'l-ekrem... ${ }^{58}$

Okçuzâde Mehmed Şâhî de mektup boyunca söz konusu "sâhib-mekremet” in cömertliği, yardımseverliği ve adaletini uzun uzun övmektedir. Aynı şekilde bazı sıhhatnâmelerde "klasik kasidelerde görülen methiye bölümüne rastlan(ır). (...) Sözgelimi Cevrî ve Zâhî̀nin sıhhat-nâmelerinin büyük bir kısmı, padişah methiyesidir." ${ }^{99}$ Dolayısıyla bazı sıhhatnâmelerin âdeta methiye kasidesine dö-

56 "Râmî Efendi hummâ-zede oldukda yazılmışdur" başlıklı yyâdetnâme için bkz. Yûsuf Nâbî, Münşeât-ı Nâbî, s. 356-7.

57 Mektupların bölümleri hakkında geniş bilgi için bkz. Derdiyok, "Mesīhịinnin Gül-i Sadberg'i”, s. 54-64; Kaşka, "Dîvân Edebiyatı'nda Münşeât Geleneği”, s. 25-9; Gültekin, “Türk Edebiyatında İnşầ, s. 288-92. Sıralaması değişiklik göstermekle birlikte davet, elkâb, dua, nakil gibi bölümlerden (rükün) oluşan (bkz. Kütükoğlu, Osmanlı Belgelerinin Dili, s. 207-11) telhislerde de padişah için övgü sözleri kullanılmıştır.

58 Konuk, "Vânî Mehmet Efendi’nin Münşe’âtı", s. 58-9.

59 Gökalp, "Divan Şiirinde Sıhhat-nâmeler”, s. 117-8. Alıntıda Cevrînnin kendi ifâkati için değil, IV. Murad'ın (salt. 1623-1640) ayağının iyileşmesi üzerine yazdığı kaside (K6) kastedilmektedir. Burada şunu belirtmekte fayda var: Makalede, daha önceki çalışmalarda sıhhatnâmelerle ilgili üzerinde durulan noktalar örneklenmedi, bunlar kısaca zikredilerek geçildi. Ancak sıhhatnâmelerin -bilhassa şifa temennisi içerenlerin- diğer makalelerde değinilmeyen özellikleri beyitlerle somutlaştırıldı. 
nüştüğü görülmektedir. Bu durum hastalık ve iyileşmenin sanatçılar tarafından muhataba ulaşmada bir vesile olarak kullanıldığının bir göstergesidir.

Sıhhatnâmeler üzerine ilk geniş araştırmayı yapan Mehmet Arslan, çoğu III. Ahmed'in iyileşmesi üzerine yazılan on sekiz sıhhatnâmeden yola çıkarak bu tür manzumelerde sıralaması değişkenlik gösterebilen bir plan uygulandığını belirtir. Buna göre şairler manzumelerin giriş kısmında muhatap -ki Arslan'a göre bu devrin padişahıdır- iyileştiği için Allah'a hamd eder, daha sonra hastalıkla ilgili bilgi verip hastalığın muhataptaki etkilerini anlatır. Muhatabın hastalığı karşısında halkın durumu ve duyduğu üzüntünün şairane bir şekilde anlatıldığı bölümün ardından yine halkın muhatabın iyileşmesi için dua edip adak adamasından bahsedilir. "Müjde bölümü”nde hastanın iyileşmesiyle birlikte halkın sevinci anlatılır ve manzume şairin muhataba/padişaha duasılyla son bulur. ${ }^{60}$ Daha sonra tespit edilen sıhhatnâmelerden bu tür manzumelerin tümünün bu bölümlerin yine tümünü içermediği anlaşılmaktadır. ${ }^{61}$

Şu an için ulaşabildiğim ıyâdetnâmeler arasında Mesîhî, Mehmed Şâhî, Nâbî ve Nevres'inkiler muhatabın iyileşme haberi üzerine yazılmıştır. Özellikle Mesîhî̀nin mektuplarında Arslan'ın sıhhatnâmelerle ilgili sıraladığı muhteva unsurlarının çoğu yer alırken bazı farklılıklar da bulunur. Mesîhî, mektuplarından birine (76) -süslü bir girişten sonra- ${ }^{62}$ Ahmed-i Dâî ve Hafız Hüsâm’ın Teressül adlı eserleri ve Menâhicü'l-İnşầda uygulamalı olarak gösterildiği gibi muhatabın hastalığını "duyduğunu" belirterek başlar. ${ }^{63}$ Daha sonra yine bu metinlerde ve

60 Arslan, "Sıhhatnâmeler", s. 778-83.

61 Gökalp, "Divan Şiirinde Sihhat-nâmeler”, s. 117.

$62 \mathrm{Bu}$ süslü girişin içerik bakımından Teressüller ve Menâhicüll-İnşâd da selam, özlem, övgü, hayır dua ve kulluğun sunulduğu, ayet ve beyitlerle süslenen kısma karşılık geldiği anlaşılmaktadır. Örnek metinler için bkz. Kırımlu Hafız Hüsam, Teressül, s. 55-6 ve 99-100; Haksever, “Ahmed-i Dâînin Teressülü”, s. 1272 ve Yahyâ bin Mehmed el-Kâtib, Menâhicüll-İnşâ, s. 94. Ayrıca bkz. Okçuzâde Mehmed Şâhî, Münşe’ât, vr. 19b. Burada şunu da belirtmek gerekir: Yazılış amacı farklı olsa da Mesîhînnin mektupları, teori kitaplarında da yer alan şifa temennisiyle yazılmış mektup örneklerine yapı olarak çok benzer. Bazı ek söylemler olmakla birlikte bunlar genellikle selam/özlem/övgü/dua/kulluk bildirimi, hastalığın işitilmesi, yazarın üzüntüsü ve dua bölümünden oluşurlar. Mesîhînnin mektuplarının farkı iyileşmeyle birlikte yazarın üzüntüsünün sevince dönüşümünü ve bu habere hamdi de içermeleridir. Ayrıca muhataba edilen duanın muhtevası değişmiştir.

63 Makale boyunca metinler arasındaki benzerliklerin daha net anlaşılması için söz konusu ifadeler dipnotlarda verilecektir: "Mahfî ve pûşîde olmaya ki zât-1 şerîf ü 'unsur-1 latîf bundan esbak niçe eyyâm câdde-i i'tidâlden cânib-i i'tilâle mầil olup mizâc-1 mübâreke 
ayrıca sıhhatnâmelerde olduğu gibi bu haberin kendi üzerindeki etkisini/üzüntüsünü şairane bir şekilde anlatır. ${ }^{64}$ Münşî Gül-i Sad-berg'deki diğer yyâdetnâmesinde (73) ise halkın üzüntüsünü dile getirmiştir ki bu bölüm pek çok sıhhatnâmede de yer alır. ${ }^{65}$ Nevres ise bu haberin muhatabın dost ve duacılarındaki etkisini sıhhatnâmelerde de çokça kullanılan bir şekilde, yani Arslan'ın da dikkat çektiği "ten, ruh, cân münasebeti”"66 ile anlatır. Buna göre şairler hastalanan zatların, bedene benzeyen âlemin canı/ruhu olduğunu belirtirler. Dolayısıyla ruh hasta olunca beden de hastalanır/ölür, ruh sıhhate kavuşunca beden yani cihan da hayat bulur. Şâkir mahlasını kullanan Gümrükçüzâde Hüseyin (ö. 1157/1744-5) ve Seyyid Vehbînnin beyitleri şöyledir:

Rûh-1 ebdân-1 cihân hazret-i Sultân Ahmed

Kuvvet-i kalb-i enâm pâdişeh-i sâhib-nâm

Rûh-1 'âlem olıcak ârızadan âzürde

Tende râhat mı kalur cânda safâ dilde kıvâm (Şâkir, K2/23, 44)

Tâze cân buldı cihân 'îd-i dü-bâlâ oldı

Sihhat-i tab'-1 humâyûn-1 hıdîv-i zî-şân (Seyyid Vehbî) ${ }^{67}$

inhirâf 'ârızasınuñ ahbâr-ı nâ-sezâsı istimâ‘ olındukda..." (Derdiyok, "Mesịhỉnnin Gül-i Sad-berg'i”, s. 267-8). Mesîhî diğer mektubunda (73) ise muhatabın hastalandığının değil "makarr-1 aslına 'avdet itdüği(nin)" yani iyileştiğinin duyulmasından bahseder. Ayrıca bu söylem başta değil mektubun ilerleyen bölümlerinde yer alır. Telhislerde de hastalığın ya da iyileşmenin duyulması söz konusudur. Üstelik sadrazamlar özellikle müjdeli haberi/ iyileşmeyi kimden "telakkî ve istimâ‘" ettiğini -ki bu hekimbaşıdır- belirtebilmektedir. Bkz. Yıldız, "Telhis, Takrir ve Buyuruldu Mecmuası", s. 114, 115 ve 117-8.

64 "Hakk 'alîmdür ki âteş-i gam mültehib ve leşker-i sabr muztarib olup 'rûhî bi-rûhike memzûcün ve muttasılün fe-külli 'ârızatihi tü’zîke tü’zînî muktezâsınca bu cân-1 hazîne bu nev'i gam ve bu dil-i gam-gîne bu sınf elem yüz gösterüp perîşân-hâl iken...” (Derdiyok, "Mesịhì’nin Gül-i Sad-berg'i”, s. 268).

65 “... hâss u âmm karîn-i hayret ü hem-nişîn-i zucret olmış idi." (Derdiyok, "Mesịhịnnin Gül-i Sad-berg'i”, s. 263).

66 Arslan, "Sihhatnâmeler", s. 785.

67 Vehbî̀nin sıhhatnâmesi divanında yer almadığı için beyit Arslan'dan aktarıldı. (Bkz. Arslan, "Sıhhatnâmeler", s. 788). Arslan makalesinde kullandığı sıhhatnâme metinlerinin pek çoğuna Topkapı Sarayı Müzesi Ktp. Revan no. 826'da bulunan Sıhhat-nâme ve Sûr-ı Hıtâna Müte'allik Kasẩid adlı mecmûadan ulaşmışır. 
Nevres de benzer şekilde 1yâdetnâmesinde "rûh-1 ebdân-1 bendegân ve cân-1 ecsâd-ı hayr-hvâhân” olarak nitelendirdiği Abdürrahîm Monla'nın hastalığının üzüntüsüyle dostlarının ve duacılarının muzdarip ve bî-cân olduğunu mecazlı şekilde söyler. Daha sonra hastanın iyileşme müjdesinin "mürde-dilân-1 âlemiyân”a taze hayat verdiğini dile getirir. ${ }^{68}$

Mesîhî, halkın üzüntüsünü belirttikten sonra 73. mektubuna yine sıhhatnâmelere benzer şekilde sabah akşam dua ettiğini söyleyerek ve muhatabın şifa bulmasına hamd ederek devam eder. Sonra kaleminin şükür secdesi yapıp bu mektubu yazdığını ifade eder. Iyâdetnâme hamd ibareleri ve sıhhatnâmelerdeki gibi muhataba dua edilerek son bulur. ${ }^{69}$ Münşî 76. mektubu ise şifa haberini alınca hamd ettiğini ve şükür secdesi yaptığını dile getirerek bitirir. Şükür secdesi yapma veya şükür için bir metin/eser yazma ${ }^{70}-\mathrm{ki}$ bu Mesîhî̀nin kaleminin şükür secdesi yapıp söz konusu mektubu yazmasının karşılığıdır- sıhhatnâmelerde de kullanılan motiflerdendir. ${ }^{71}$ Gümrükçüzâde Hüseyin (Şâkir) ile Pîrîzâde Sâhib’in (ö. 1162/1749) aşağıdaki beyitleri Mesîhî nin söz konusu ifadelerinin benzeridir:

Secde-i şükre idüp vaz'-1 cebîn-i ihlâs

Eyledüm hamd-i firâvân-1 Hudâyya ikdâm (Şâkir, K2/48)

Kerem-kâra bu sıhhat-nâmeyi inşâd idüp tab'im

Berây-1 şükr-i sıhhat eyledi itmâmına dikkat (Sâhib) ${ }^{72}$

68 Elçi, "Nevres-i Kadîm’in Münşeâtı”, s. 247. Telhislerde de padişahlar için "rûh-1 cüsmân-1 cihân" ve "rûh-1 ebdân-1 âlem" tabirleri kullanılır. Örnekler için bkz. Yıldız, "Telhis, Takrir ve Buyuruldu Mecmuası”, s. 59, 73, 114, 117. Râgıb Paşa hastalığından dolayı padişahın şerbet içmesi için yazdığı telhiste münşî ve şairler gibi "rûh-1 cüsmân-1 cihân" olan padişahın iyileşmesinin "bấis-i sıhhat-i âlemiyân ve mûris-i ten-dürüstî-i âdemiyân" olduğunu belirtir. Bkz. Özel, "Koca Râgıb Mehmed Paşa'nın Münşê̂t ve Telhîsâtı”, s. 142.

69 “Cenâb-1 'izzetden me'mûldür ki vücûd-1 şerîfünüüz ilâ-yevmi'l-haşr ve't-tenâdd sebeb-i izdiyâd-1 devlet ü mûcib-i imtidâd-1 'izzet vâki‘ ola. Âmîn yâ Mücîbe’s-sẩilîn” (Derdiyok, "Mesīhì̄nin Gül-i Sad-berg'i”, s. 264).

$70 \mathrm{Bu}$ konuda yazdığım makalenin yakın zamanda yayımlanacağını ümit ediyorum.

71 Daha önce de belirtildiği gibi telhislerde de sadrazamlar hastalık haberinin kendilerini ne derece üzdügünü ve padişah için devamlı dua ettiklerini dile getirdikten sonra iyileşmeyle yaşadıkları sevinci ve hamd edip şükür secdesi yaptıklarını anlatırlar. Yine sadrazamların ifadelerine göre söz konusu telhisler bu şükrün/teşekkürün bir yolu olarak yazılmıştır. Örnekler için bkz. Yıldız, "Telhis, Takrir ve Buyuruldu Mecmuası”, s. 113-8.

72 Sâhib'in sıhhatnâmesi divanında yer almadığı için beyit Arslan'dan aktarıldı. (Bkz. Arslan, "Sihhatnâmeler", s. 778). 
Şehdînnin (ö. 1140/1727) sıhhatnâmesinin başlı̆̆ında da manzumenin padişahın iyileşmesinin "şükrâne"si için yazıldığı bilgisi yer almaktadır.

Her iki mektupta dikkat çeken bir diğer husus da Mesîhînnin iyileşme haberinin alınmasından önce ve sonra kendisinin/halkın ruh hâlini karşılaştırarak betimlemesidir. Bu haberden önce ümitsiz ve sıkıntıda olduğunu söyleyen münşî haberle birlikte neşeye ve âdeta yeni bir hayata kavuşmuştur. ${ }^{73}$ Nâbî ise bir gemiye benzettiği gönlünün ızdırap dalgalarının verdiği sıkıntıdan kurtulduğunu söyleyerek duygularını dile getirir. ${ }^{74}$ Sıhhatnâmelerde de bunlara benzer söyleyiş biçimlerine sıklıkla rastlanır. Örneğin Kâmî III. Ahmed için yazdığı terci-bendinde kendinin ve tüm dünyanın bu haberle gam ve kederden kurtulup sevince gark olmasını bir başka deyişle hayatlarının değişimini anlatmaktadır. Üzüntüden suskunlaşan şairin bu müjdeyle bülbüle dönüp neşelenmesinden -diğer tüm şairlerle birlikte şiirler/sıhhatnâmeler yazmasına da imada bulunarak- bahsetmesi Mesîhî̀nin kaleminin şükür secdesiyle mektup üretmesi ile paralellik göstermektedir:

Çeşm-i bîmâr-1 dil-ârâda olan hâlet ile

Rûh-1 âlemde nümâyân idi za'f ile elem

Müjde-i sıhhati şâd itdi bütün dünyâyı

Böyle eyyâm-1 sürûr içre çi endûh u çi gam

Tab'-1 şûrîdemüz oldı bu ferahla bülbül

Nice dem olmış iken hüzn ile lâl ü ebkem (Kâmî, Ms1/I)

İyileşme haberi üzerine yazılan ıyâdetnâmelerle sıhhatnâmeler arasında bazı farklar da bulunmaktadır. Örneğin manzum metinlerde hastanın iyileşmesine hamd genellikle metnin başında bulunurken ${ }^{75}$ Mesîhî, Okçuzâde Mehmed Şâhî ve

73 “(...) muhabbir-i sâdık-1 sürûr-bahş haber-i hayât-efzâ virüp eğerçi sâbıkan rûh-1 hayvânî terbiyet-i tenden 'âtıl ve kuvâ-yı cismânî tedbîr-i bedenden zâhil olup haylice müzayaka çekmişlerdür." (Derdiyok, "Mesịhỉ’nin Gül-i Sad-berg'i”, s. 268), "Eğerçi ol esnâda şîşe-i ümîdümüz seng-i havâdis-i rûzgârdan şikeste vü beste idi. Ammâ bu haber mûmyâsından sıhhat 'alâ’imi belürdüği sebebden hâme-i miskîn 'imâme ile secde-i şükre varup..." (Derdiyok, "Mesịhị’nin Gül-i Sad-berg'i”, s. 263).

74 "keştî-i hâtırumuz telâş-1 mevce-i ıztırâbdan vâ-reste olup..." Yûsuf Nâbî, Münşeât-ı Nâbî, s. 356.

75 Arslan, "Sıhhatnâmeler", s. 778; Gökalp, "Divan Şiirinde Sihhat-nâmeler", s. 118-9. Aslında farklı tür ve biçimlerdeki manzumelerde bulunan hamd/şükür ifadelerini inceleyen makalemde bunun her zaman geçerli olmadığını, bu söylemin son beyit de dâhil olmak 
Nâbî̀nin mektuplarında -telhislerde olduğu gibi- ilerleyen kısımlarda yer almıştır. Nevres'in mektubunda ise hamd kısmı bulunmamaktadır. Ayrıca bunlarda hastalıkla ilgili detaylı bilgi verilmemiş, Nâbî hastalığın adını anarak Râmî Paşa’nın hummaya tutulduğunu söylemiştir. Okçuzâde bunu bile yapmamış, sadece söz konusu sâhib-mekremetin "pûte-i a'râz-1 emrâzdan halâs ve tengnâ-yı aksâm-1 eskâmdan infilâs bul(duğu)" "76 bilgisini vermiştir. Mesîhî ise muhatabına "ârıza-i maraz ârız ol(duğunu)" ya da mübarek mizacında "inhirâf ârızası" görüldüğünü söylemiştir. ${ }^{77}$ Ancak Mesîhî yukarıda da alıntılandığı gibi (bkz. 64. dipnot) hastalık haberinin kendisi üzerindeki etkilerini/üzüntüsünü anlatırken "âteş, mültehib, muztarib, gam, elem, perîşân-hâl” gibi kelimeleri kullanarak bir bakıma hastalığa ve sonuçlarına gönderme yapar. Dolayısıyla sıhhatnâmelerde muhatabı anlatırken kullanılan hastalıkla ilgili terminoloji Mesîhînnin ıyâdetnâmesinde sanatlı bir şekilde mektup yazarının ruh hâlini tasvir için kullanılmıştır. Mesîhînnin mektubunun sonunda -imza kısmında- kendisini "el-fakîr ü zâr Mesîhî-i bîmâr"78 olarak nitelendirmesi bu durumun bir diğer göstergesidir.

Müjde haberiyle yaşanan sevincin, dolayısıyla hamdin yer almadığı ve henüz hastalıktan kurtulamamış muhataba şifa temennisiyle yazılan ıyâdetnâme ve sıhhatnâmeler ise yine hastalık haberinin "işitilmesi/öğrenilmesi” üzerine duyulan üzüntünün ifadesini içermektedir. Cevapnâme niteliğindeki mektuplarında Lâmiî ve Şeref Hanım (M4) bu haberi muhataplarının kendilerine gönderdiği mektuptan öğrenmişlerdir. Bu cevapnâmelerde her iki müellif de muhataplarının “işittikleri” hastalığı hakkında kısa bilgi verirler. Şöyle ki Şeref Hanım yalnızca muhatabının sıtmaya yakalandığını belirtirken (M4/4, ayrıca bk. b. 6-7) Lâmiî biraz daha ayrıntılı şekilde muhatabının 'teb'e tutulduğu bilgisini verir. Şair ve yazarlar bu metinlerde de aldıkları bu kötü haberin kendileri/toplum üzerindeki etkilerinden bahsederler. Örneğin Çelebizâde Âsım, Nakşî Efendi adlı zat için yazdığı ıyâdetnâmesinde ${ }^{79}$ muhatabının hastalığını duymasının gönül çeşmesinin bozulmasına sebep olduğunu söylerken Vanî Mehmed Efendi Silahdar'a yazdığı

üzere metnin herhangi bir yerinde yer alabildiğini tespit etmiştim. Bkz. Betül Sinan Nizam, “Divan Şairi Neye Hamd Eder, Niye Şükreder? Bir Anlatım Biçimi Olarak Hamd”, Türk Kültürü Incelemeleri Dergisi, 39 (2018), s. 170, 177.

76 Okçuzâde Mehmed Şâhî, Münşe’ât, vr. 19b.

77 Derdiyok, "Mesîhìnnin Gül-i Sad-berg'i”, s. 263 ve 268.

78 Derdiyok, "Mesīhīnnin Gül-i Sad-berg'i”, s. 269.

79 "Bu dahi mûma-ileyh Nakşî Efendi' niñ istifsâr-1 hâtırları içün tesvîd buyurdukları tezkere sûretidir” şeklinde isimlendirilmiş mektubun metni için bkz. Küçük Çelebi-zâde İsmâ̂̂ll Âsım Efendi, Münşềt-ı Âsım, haz. Fahri Unan (Ankara: TTK, 2013), s. 174-5. 
mektupta tüm halkın padişahın yüce mizaclarının değişiminden büyük üzüntü duyduğunu belirtir. Şeref Hanım ise divanındaki mesnevi biçimindeki mektupların birinde, muhatabının hastalığını duyduğunu belirttikten sonra hastalığın kendisi üzerindeki etkisini Ferhâd ile Mecnûn'un adını anarak anlatır. Bu etkinin bu şekilde telmih sanatı yoluyla anlatımı mektubun manzum olarak yazılmasından kaynaklanıyor olmalıdır:

Nâ-mizâc oldığıñı gûş itdim

Mevc-i deryâ gibi çok cûş itdim

O haber vâsıl olunca câna

Eşk-i çeşmimle boyandım kana

Hâlime şâd ile mahzûn ağlar

Görse Ferhâd ile Mecnûn ağlar (Şeref Hanım, M5/5-7)

Şifa duasıyla yazılan ıyâdetnâme ve sıhhatnâmelerde muhatap için farklı temennilerde bulunulur. Örneğin birbirine çok benzeyen yyâdetnâme örneklerinde Kırımlı Hafız Hüsâm ve Yahyâ b. Mehmed el-Kâtib hastalığın muhatabın vücudundan ırak olmasını dileyip vücuduna "sağlıklar yaraş(tığını)" ve "sıhhatler erzânî (olduğunu)" belirtir. ${ }^{80}$ Müellifler bundan sonra hastalıktan kaynaklanan bu dert ve sıkıntının düşmana nasip olmasını, muhataba kötü niyet besleyenlerin inlemesini ister. Aynı söylem Ahmed Paşa’nın sıhhatnâmesinde de bulunmaktadır:

Yâ Rab bu devlet bedrini kurtar husûf-1 za'fdan

İzzet göğinde ol meh-i tâbâna sıhhat yaraşur

Nakl olsun ol derd ü elem a'dâña ey kân-1 kerem

Tâ haşre dek sen menba'-1 ihsâna sıhhat yaraşur (Ahmed Paşa, K32/16-17)

Nevres de çaresizce haset ve kin hastalığına yakalanmış düşmanın mezara girmesi için dua ettiği konusunda muhatabını bilgilendirir.

Lâmiî Çelebi ise "dârü’ş-şifâ-i gaybden ve 'inâyet-hâne-i lâ-raybden” muhatabının payına zamanın doktor ve bilginlerine ihtiyaç kalmadan iyileşmenin düşmesini dilerken Şeref Hanım gazel biçimindeki sıhhatnâmesinde uzun süredir hasta olması sebebiyle göremediği dildârı için benzer bir temennide bulunur:

80 Kırımlu Hafız Hüsam, Teressül, s. 56; Yahyâ bin Mehmed el-Kâtib, Menâhicül-İnşâ, s. 94. 
Vir şifâ-hâne-i feyziñden 'ilâc-1 'âcil

Koma Lokmân ile Eflâtun'a hâcet yâ Rab (Şeref Hanım, G19/6)

Çelebizâde Âsım'ın Lütfullâh Efendi'ye yazdığı 1yâdetnâmenin ${ }^{81}$ giriş bölümündeki Farsça beyit ${ }^{82}$ de benzer anlamlar ihtiva etmektedir.

Vanînnin hayır dualar içeren mektubu padişaha yazılması bakımından muhatabın yine padişah olduğu sıhhatnâmelere çokça benzemektedir. Yazar mektubunda sıhhatnâmelerde olduğu gibi gece gündüz demeden herkesin padişahın iyileşmesi için dua ettiği bilgisini verir. ${ }^{83}$ Ahmed Paşa ise aşağıdaki beyitte benzer bir söylemi tekrar etmektedir:

Her gûşede tesbîh ider dilli dilince kầinât

Zikri budur kim Hazret-i Sultân'a sıhhat yaraşur (Ahmed Paşa, K32/4)

Her ne kadar Âsım bir mektubunda hasta muhatabı için tek yapabileceğinin dua etmek olduğunu belirtse ${ }^{84}$ de bu tür yyâdetnâmelerde münşîlerin muhatabı teselli ederek ve ona tavsiyelerde bulunarak daha fazlasını yaptıkları da görülür. Örneğin Menâhicü'l-İnşâdda Allah'ın sevdiği kulunun vücuduna hastalık verip sabrını sınadığı hatırlatılmış ve ayetlerden yapılan iktibaslarla Kur'ân'da Hz. Eyüb’ün övüldügü belirtilmiştir. Dolayısıyla ecre müstahak olabilmek için sabrı ve rıza-yı Hakk'ı elden komama tavsiyesinde bulunulur. Lâmiî ise yaptığı alıntılarla hastalığın Müslümanlar için günahları yok etme yolu, dolayısıyla hayır/rahmet olduğunu hatırlatarak muhataba teselli verir. Âsım'ın Lütfullâh Efendi'ye yazdığı ıyâdetnâme ise daha somut tavsiyeler içermesi bakımından dikkat çeker. Âsım

81 "Müşârun ileyh hazretleriniń evân-1 bîmârîlerinde istifsâr-1 hâtır-1 şerîflerini mutazammın tesvîd buyurdukları tezkere sûretidir” başlıklı mektubun metni için bkz. Küçük Çelebizâde İsmầîl Âsım Efendi, Münşe’ât-ı Âsım, s. 99-100.

82 Gerek teori kitaplarında gerek münşeâtlardaki örneklerde Arapça ve özellikle Farsça söylenmiş mısra, beyit ve kıtalara rastlanmaktadır. Diğer örnekler için bkz. Kırımlu Hafız Hüsam, Teressül, s. 56; Yahyâ bin Mehmed el-Kâtib, Menâhicüll-İnşâ, s. 94; Karaman, "Lamiî Çelebi'nin Münşeâtı”, s. 78; Okçuzâde Mehmed Şâhî, Münşeâat, vr. 19b, 20a, 20b, 21 a.

83 "leyl ü nehâr evlâd ü etbâ'-i fukarâsıyla rûy-1 niyâz zemîn-i zarâ‘ate nihâde ve dest-i duâ semâ-yı icâbete küşâde kılınup devletlü ve şevketlü pâdişâhımıñ vücûd-1 mes'̂ud-1 hümâyûnları mükeddirât-1 kevniyyeden masûn ve tegayyurât-1 dünyevîden me’mûn olmak du âsı kemâ yenbagî edâ kılınur." (Konuk, "Vânî Mehmet Efendi’nin Münşeâtı”, s. 59).

84 "Ancak 'elimizden ne gelür hayr-duâadan gayri' mefhûmu üzre merhem-i Süleymânî-i du ầ-yı bî-riyâ ile tedbîr-i devâya mübâderet kılınmışdır." (Küçük Çelebi-zâde İ́smầîl Âsım Efendi, Münşe'ât-ı Âsım, s. 175). 
muhatabından -meyve yemeye düşkünlüğünden dolayı daha önce de birkaç kez rahatsızlandığını hatırlatarak-"el-mi'detü re’sü külli devâ̂”" ${ }^{55}$ manası üzere zararlı olabilecek şeylerden kaçınarak perhiz etmesini ister. Dolayısıyla Âsım mektubunda hastalığın teşhisini koyup tedavi yöntemini de belirterek muhatabın kendini muhafaza etmesinin yolunu göstermiş olur. Netice olarak iyileşmeyi tebrik için yazılan ryâdetnâmelerdeki üzüntünün sevince dönüşümü bunlarda yerini teselli, sabır, ümit duyguları ile tavsiyelere bırakmıştır, denebilir.

Bu tür mektuplarda karşılaşılan bir diğer söylem de münşînin hastayı çeşitli sebeplerden ziyaret edememesinden dolayı mazur görülme isteğidir. Örneğin Hafız Hüsâm örnek mektubunda şöyle der: "Hakk 'alîmdür ki bu kemîne muhibbünüze vâcib ve lâzımidi kim baş üzerine varup mübârek vücûduñuzı hestelik zahmetinden sormak. Ammâ 'alâyık-ı rûzigâr mâni‘ olduğıçün kademden kaleme ihtisâr ve iktifâ olındı. Ma'zûr tutasız." ${ }^{86}$ Burada ayrıca Mesîhînnin mektubunda yazarın şükrünün vesilesi olan kalemin şifa dileklerinin yazılması için kullanıldığı görülmektedir. Iyâdetnâmesinde özrünü beyan yerine muhatabını hasta görmediği için şükreden Âsım ise bu konuda yine diğer münşîlerden ayrılır. Yazar Lütfullâh Efendi'yi ziyarete gidecekken hava muhalefeti sonucu deniz ulaşımının aksaması nedeniyle bu düşüncesini yerine getirememiş ${ }^{87}$ ve Lütfullâh Efendi tam da o gece hastalanmıştır. Âsım bunun üzerine "ve ol gece zücâc-1 safvet imtizâcları âlûde-i gubâr-1 'illet olmağla, zât-1 ma âlî-simâtlarını münharifü'lmizâc ve muhtâc-1 tedbîr ü 'ilâc görmediğimize edâ-yı secde-i şükr-i Hudâ ve şifâhâne-i kerem-i İlâhîden şîrîn-kâm-1 şehd-i sıhhat-i tâmme olmalarına hulûs-1 kalb ile teveccüh ü du'â kılınmışdır." ${ }^{88}$ diyerek farklı bir sebeple de olsa ilk gruptaki 1yâdetnâme yazarları gibi hamd etmiştir.

Son olarak ister iyileşmeyi tebrik etmek ister şifa dilemek için yazılsın ryâdetnâmelerde -diğer mektup türlerinde de olduğu gibi- ayet, hadis veya kelam-1 kibarlardan pek çok alıntı yapıldığının altı çizilmelidir. Münşîler Allah’ın şefkat ve rahmetinin, şifa ve huzur verici oluşunun vurgulandığ (Bakara 1/207, İsrâ 17/82, Şuarâ 26/80, Fâtır 35/34), sabrın övüldüğü (Sâd 38/44, Zümer 39/10) ayetleri; hastalığın Müslümanlar için nimet olduğuna dair hadis veya kelam-1 kibarları; sağlık için alınması gerekli tedbirleri anlatan sözleri muhataplarının iyileşmelerini

85 "Her devanın başı midedir."

86 Kırımlu Hafız Hüsam, Teressül, s. 56.

87 Âsım söz konusu ryâdetnâmeden hemen önce yer alan itizarnâmesinde Lütfullâh Efendi’ye bu nedenle özrünü beyan eder. Bkz. Küçük Çelebi-zâde İsmâ’̂̂l Âsım Efendi, Münşe’ât-ı Âsım, s. 98-9.

88 Küçük Çelebi-zâde İsmầ̂l Âsım Efendi, Münşe’ât-ı Âsım, s. 99. 
kutlamak veya onlara dua edip teselli ve tavsiye vermek üzere kullanmışlardır. ${ }^{89}$ Okçuzâde Mehmed Şâhî farklı olarak muhatabının cömertliğine sık sık dikkat çektiği ıyâdetnâmesinde yardımın ve isteklerin giderilmesinin faziletlerinin vurgulandığı hadislerden de iktibaslar yapmıştır. ${ }^{90}$ Sıhhatnâmelerde ise iktibaslara çok az rastlanır. Sâmî (ö. 1146/1734) ${ }^{91}$ aşağıdaki beyitlerde III. Ahmed'in hummadan iyileşmesini bayram ve sonrasında yapılan sünnet düğünü ile birlikte anar. Zira Silahdar Fındıklılı Mehmed Ağa’nın (ö. 1139/1726-7) Zeyl-i Fezleke (Silahdar Taribi) adlı Osmanlı tarihinin devamı niteliğindeki Nusretnâme'sinde anlatıldığı üzere Sultan Ahmed 1132'de (1720) hummadan nâ-hoş mizac olduğunda ramazanın dokuzuncu pazartesi günü istirahat ettiği Beşiktaş Sarayı'ndan Yeni Saray'a (Topkapı Sarayı) geçmiş ve tashih-i mizac edinceye kadar Harem-i şerifleri ile burada kalmıştır. ${ }^{92}$ Mehmed Ağa Sultan'ın çok geçmeden sıhhat ü afiyet bulduğunu ve ramazanın yirmi birinci cuma günü vüzera, ulema ve meşayihin Sofa Köşkü’ne davet edilip hırka-i şerif açılarak dualar okunduğunu söyler. ${ }^{93}$ Osmanlı şairleri de Padişah'ın bayrama az bir süre kala hummayı yenmesini çifte bayram olarak değerlendirmişlerdir. Bunun yanında bu iyileşme ve bayramdan yaklaşık bir buçuk ay sonra zilkadenin dokuzuncu perşembesi ${ }^{94}$ gerçekleştirilen Sultan Ahmed'in dört şehzadesinin sünnet dügünü kaynaklarda bu hadiselerle birlikte anılmıştır. Hatta Sıhhat-nâme ve Sûr-ı Hıtâna Müte 'allik Kasẩid adlı mecmûada

89 Örneğin Hüsâm örnek nyâdetnâmesine "Her sıhhat u şifâ ve âfiyet ü safâ ki 'Ve nunezzilü mine’l-Kur'âni mâ hüve şifầun ve rahmetün li'l-mü’minîn' (K17:82) dârû-hânesinden nâzil olup şerîf zâtuñuza ve latîf vücûduñuza mukârin ve muâvin olsun.” diyerek başlar. Bkz. Kırımlu Hafız Hüsam, Teressül, s. 55

90 Okçuzâde Mehmed Şâhî, Münşe’ât, vr. 20a, 20b.

91 Verdiği ölüm tarihinden Arslan'ın Sıhhat-nâme ve Sûr-ı Hıtâna Mütéallik Kasầid'de "Sıhhat-nâme-i Sâmî" adıyla kayıtlı kasidenin Arpaeminizâde’ye ait olduğunu düşündüğü anlaşılmakta. Gökalp de bu kanaatte olduğunu belirttikten sonra Arpaeminizâde'nin divanında bu kasidenin bulunmayışına, bu nedenle de başka bir Sâmîye ait olma ihtimaline dikkat çeker. Bkz. Gökalp, "Divan Şiirinde Sıhhat-nâmeler", s. 112.

92 Padişah'ın bu tebdil-i mekânı sıhhatnâme yazan şairler tarafından da dile getirilmiştir. Örneğin Seyyid Vehbî "Nakl idüp kasr-1 Beşiktaş'dan İstanbul'a / İtdi ta'dîl-i mizâc eyledi tebdîl-i mekân" der. Arslan metinlerden yola çıkarak bu durumu padişahın "Ramazan ayının son günlerine doğru tamamen iyileştiği ve Beşiktaş’taki köşünden şehre, halkın arasına indiği" şeklinde yorumlamıştır (Arslan, "Sıhhatnâmeler", s. 788). Ancak şairlerin Padişah'ın hastalanınca Topkapı Sarayı'na geçişini anlattıkları anlaşılıyor.

93 Mehmet Topal, "Silâhdar Fındıklılı Mehmet Ağa Nusretnâme Tahlil ve Metin (11061133/1695-1721)” (doktora tezi), Marmara Üniversitesi SBE, 2001, s. 913-4.

94 Topal, "Nusretnâme”, s. 915. 
bu iyileşme ve sonrasındaki sünnet dügünü için yazılan manzumeler bir araya getirilmiştir. İşte Sâmî de bu üç olaya gönderme yaptığı aşağıdaki beyitlerinde "Her zorlukla beraber bir kolaylık vardır." (İnşirâh, 94/5-6) müjdesini padişahın sıkıntılı günlerinden mutlu günlere geçişini anlatmak için kullanır:

Sûre-i pâk-i "elem neşrah" olup fâl-i bi-hayr

Eyledi sûr-1 humâyûn ile intâc-1 merâm

Usr idi sû̀-i mizâc irdi bi-hamdi'llâh yüsr

'Îdi ta'kîb idicek sûr-1 meserret-encâm (Sâmî) ${ }^{95}$

\section{Sonuç}

Osmanlı edebiyatı sanatçıları başta padişahlar olmak üzere devlet görevlilerine çeşitli vesilelerle ulaşmaya çalışmışlar, böylece kulluklarını/bağlılıklarını bildirmek ve kendilerinden beklendiği gibi de davranarak onlarla aralarındaki bağı kuvvetlendirmek istemişlerdir. Muhataplarının hastalanmaları ya da iyileşmeleri onların bu vesile ya da bahanelerinden yalnızca ikisidir. Dinî referanslarını muhtemelen Hz. Peygamber'in ryâdet tavsiyesi/sünnetinden alan sanatçılar bu şekilde câize, mansıb, himaye gibi beklentilerinin karşılanacağını ümit etmişlerdir. Bunun için hastalanan zatların hâllerini sormak ve şifa temennisinde bulunmak veya iyileşen kişileri tebrik etmek ve bu olaydan duydukları sevinci ifade etmek amacıyla ıyâdetnâme ve sıhhatnâme adlı mektuplar ile manzumeler kaleme almışlardırlar. Bu şekilde şair ve münşîler hasta ya da henüz şifa bulmuş muhataplarına "geçmiş olsun" demektedirler. Yakın dostlara yazılmış örnekleri de bulunan yyâdetnâme ve sıhhatnâmelerin -yazılma amaçları ya da işlevleri bakımından benzer metinler olduklarından- birbirlerinden bağımsız olarak incelenmeleri gerek barındırdıkları ortak söylemi ortaya koymak gerek içinde üretildikleri sosyal, kültürel, siyasî, tarihî, dinî, edebî ortamı anlamak açısından elbette yeterli olmayacaktır. Bu nedenle benzer motivasyonlarla oluşturulan ve aynı kurgu etrafında geliştirilen bu manzum ve mensur metinler birlikte ele alınmalıdır. Yine yakın motivasyonlarla üretilen türlerin (duânâme gibi) ve Osmanlı resmî belgelerinin (telhis gibi) de bu metinlerle ilişkisinin ortaya konması elzemdir.

Aynı amaç çerçevesinde üretilen ıyâdetnâme ve sıhhatnâmelerin (hastalık/sağlık konulu telhisler ve duânâmeler de buna dâhildir) ortak içerik, yapı

95 Beyit Arslan'dan aktarılmıştır. (Bkz. Arslan, "Sıhhatnâmeler", s. 787). 
ve söyleyiş özellikleri barındırdıkları görülmektedir. Çeşitli şekillerde “övülen” muhatabın öğrenilen/işitilen hastalığından duyulan üzüntü, iyileşmesinden duyulan sevinç ve bunun için edilen şükür; halkın/şair ya da münşînin acısının iyileşmeyle sevince dönüşümü; şifa bulma veya bir daha hastalanmama, daima huzurlu olma için edilen dua -yazılma nedenlerine göre değişiklik gösterse debu metinlerin ortak özelliklerindendir. Hamd bölümlerinin yeri, hastalıkla ilgili verilen bilginin miktarı, bazı bölümlerin (mazeret bildirme, teselli ve tavsiye verme) mevcudiyeti, ayet veya hadislerden yapılan iktibasların oranı bakımından farklılıklar içeren ıyâdetnâme ve sıhhatnâmeler yazılış amaçları, dolayısıyla işlevleri, yapı ve anlatım özellikleri bakımından -telhis ve duânâmeler gibi- aynı edebî, siyasî, dinî, kültürel geleneğin parçalarıdır. Tüm bunlarla birlikte istisnâ̂ nitelikte metinlerin varlığı da göze çarpmaktadır. Cevrînnin kendi iyileşmesini konu alan sıhhatnâmesini muhatabı olan hekime vefa borcunu ödemek için kaleme alması, Vehbî̀nin sıhhatnâme başlıklı mesnevisinin padişahın hastalık ya da ifâkat süreciyle ilgili hiçbir gönderme barındırmayıp sadece huzurlu ve mutlu olması duasını içermesi, Okçuzâde Mehmed Şâhînnin ıyâdetnâmesinin iyileşmeden duyulan sevinç yerine muhatabın cömertliğine yoğunlaşması hatta iktibasların bile çoğunlukla bunu vurgulaması şimdiye kadar tespit edilen ıyâdetnâme ve sıhhatnâmelerdeki farklı özelliklerdir. Son olarak, ulaşılacak yeni metinlerle ıyâdetnâme ve sıhhatnâmelere dair yapılan tespitlerin değişmesi ya da zenginleşmesinin mümkün olduğu hatırlatılmalıdır.

Geçmiş Olsun Dileklerini İleten Mensur ve Manzum Metinler: Iyâdetnâme ve Sibhatnâmeler

Öz - Bugüne kadar yapılan çalışmalarda hamiler ve yakın dostların hastalanmaları ya da iyileşmeleri üzerine yazılan metinlerden sıhhatnâmelere yoğunlaşılmış, ıyâdetnâmelerden bahsedilmemiştir. Oysa Osmanlı devri sanatçıları özellikle bir hastalığa yakalanmış veya sonrasında iyileşmiş devlet görevlilerine ulaşmak ve onlara geçmiş olsun dileklerini iletmek için yalnızca sıhhatnâme türünde manzumeler kaleme almamış, ıyâdetnâme adı verilen mektuplar da yazmışlardır. Bu makale benzer gayelerle üretilmiş bu manzum ve mensur metinlerin bütün yönleriyle kavranabilmesi için birlikte ele alınmaları gerektiğini savunmaktadır. Bu nedenle sıhhatnâme ve ıyâdetnâme örnekleri içerik, yapı ve anlatım özellikleri açısından karşılaştırmalı olarak incelenmiştir. Bunların benzer motivasyonlarla oluşturulan duânâmeler ve Osmanlı resmî belgelerinden telhislerle ilişkileri de üzerinde durulan konulardandır. Sonuç olarak aynı gelenek içinde oluşan bu metinlerin istisnalar ya da bazı farklılıklar olmakla beraber benzer bir kurgu etrafında şekillendikleri, başka bir deyişle ortak bir söylemi paylaştıkları anlaşılmaktadır.

Anahtar kelimeler: Sıhhatnâme, yyâdetnâme, duânâme, telhis, mektup, inşâ. 


\section{Kaynaklar}

Akalın, Serkan: "Duacı Bir Baba Olarak Mevlânâ ve Mektupları", Turkish Studies-International Periodical for the Languages, Literature and History of Turkish and Turkic, IX/3 (2014), s. 1-22.

Altuğ, Fatih: “Başka Türlü Bir Yaklaşım Mümkün mü?”, Eski Türk Edebiyatı Çalışmaları IV: Nazımdan Nesire Edebî Türler (25 Nisan 2008 Bildiriler), haz. Hatice Aynur vd., İstanbul: Turkuaz 2009, s. 32-45.

Arslan, Mehmet: "Sihhatnâmeler”, Türkler, XI (2002), s. 776-90.

Atnur, Gülhan: "Osmanlı Tıp Yazmaları ile Halk Hekimliğinde 'Hafakan (Afakan)' ve Hazâa 'İlâc-ı Hafakân Adlı Kitap”, Uluslararası Sosyal Araştırmalar Dergisi, IV/17 (2011), s. 48-62.

Ayan, Hüseyin: Cevrî-Hayâtı, Edebî Kişiliği, Eserleri ve Divanının Tenkidli Metni, Erzurum: Atatürk Üniversitesi 1981.

Aydın, Elif: Divanlardaki Manzum Mektuplar, (Yayımlanmamış Yüksek Lisans Tezi) Adana: Çukurova Üniversitesi SBE, 2007.

Batislam, Dilek: “Mesnevilerde Mektup Tarzı Anlatım”, İlmî Araştırmalar, 13 (2002), s. 17-34.

Coşkun, Vildan Serdaroğlu: "Sergüzeştüm Güzel Hikâyetdür" Zaîfînnin Sergüzeştnâme’si, İstanbul: İSAM 2013.

Çakır, Ömer: Türk Edebiyatında Mektup, (Yayımlanmamış Doktora Tezi) Ankara: Gazi Üniversitesi SBE, 2005.

Çiçekler, Ahmet Naim ve Mehmet Gürlek: "Osmanlı Tıp Metinlerinde Geçen Hastalık Adları Üzerine”, Turkish Studies-International Periodical for the Languages, Literature and History of Turkish and Turkic, XI/21 (2005), s. 95-112.

Çolak, Ali: "Hasta Ziyareti İle İlgili Hadisler Bağlamında Bir İnceleme”, EKEV Akademi Dergisi, 48 (2011), s. 161-76.

Daş, Abdurrahman: Osmanlılarda Münşeât Geleneği, Hoca Sadeddin Efendi'nin Hayatı, Eserleri, Münşeâtı, (Yayımlanmamış Doktora Tezi) Ankara: Ankara Üniversitesi SBE, 2003.

Deniz, Sebahat: "Kadızâde Mehmed İlmî̀nin Sultan IV. Murad İçin Yazdığı Manzum Duânâme'si”, Divan Edebiyatı Araştırmaları Dergisi, 1 (2008), s. 9-40.

Derdiyok, İ. Çetin: XV. Yüzyıl Şāirlerinden Mesīhı̈nin Gül-i Sad-berg’i, (Yayımlanmamış Doktora Tezi) Adana: Çukurova Üniversitesi SBE, 1994.

....... "Osmanlı Devrinde Mektup Yazma Geleneği”, Osmanlı, IX (Ankara 1994), s. 731-40.

Dikmen, Hamit: Seyyid Vehbi ve Divanının Karşılaştırmalı Metni, (Yayımlanmamış Doktora Tezi), Ankara: Ankara Üniversitesi SBE, 1991. 
Durmuş, İsmail: “Mektup (Arap Edebiyatı)”, DİA, XXIX (2004), s. 14-6.

Edirneli Kâmî: Kâmî Dîvânı, haz. Gülgün Erişen Yazıcı, Ankara: T.C. Kültür ve Turizm Bakanlığı Kütüphaneler ve Yayımlar Genel Müdürlüğü 2017.

Elçi, Fatih: Nevres-i Kadîm’in Münşeâtı (İnceleme-Metin), (Yayımlanmamış Doktora Tezi) Adıyaman: Adıyaman Üniversitesi SBE, 2017.

Fodor, Pál: “Telhis”, DİA, XL (2011), s. 402-4.

Gökalp, Halûk: “Divan Şiirinde Sıhhat-nâmeler”, Türk Kültürü İncelemeleri Dergisi, 14 (2006), s. 101-30.

, "Seyyid Vehbînnin Divanında Yer Almayan Bir Kasidesi”, Turkish Studies-International Periodical for the Languages, Literature and History of Turkish and Turkic, VIII/1 (2013), s. 299-314.

Gökçe, Recep: Eski Türk Edebiyatında Mektup ve Bir Mecmû'a-i Münşeât, (Yayımlanmamış Yüksek Lisans Tezi) Kayseri: Erciyes Üniversitesi SBE, 2006.

Gültekin, Hasan: Türk Edebiyatında İnşâ: Tarihî Gelişim-Kuram-Sözlük ve Metin, (Yayımlanmamış Doktora Tezi) Ankara: Hacettepe Üniversitesi SBE, 2007.

Haksever, Halil İbrahim: "Ahmed-i Dâinnin Teressülü”, Turkish Studies-International Periodical for the Languages, Literature and History of Turkish and Turkic, VI/1 (2011), s. 1265-73.

İnce, Ömer: İnşâ-i Merğ $\hat{u} b$ ve İlm-i İnşẩda Müsta'mel Lügatler, (Yayımlanmamış Doktora Tezi) İzmir: Ege Üniversitesi SBE, 2007.

İsyânî, Gazeliyyât-ı İsyânı̂, Millet Ktp., AE Manzum, no. 300.

Kandemir, M. Yaşar: “Ziyaret”, DİA, XLIV (2014), s. 496-8.

Karahan, Abdülkadir: "Nâbî”, DİA, XXXII (2006), s. 258-60.

Karaman, Hüseyin: Lamî̂ Çelebi’nin Münşeâtı, (Yayımlanmamış Yüksek Lisans Tezi) Afyon: Afyon Kocatepe Üniversitesi SBE, 2001.

Kaşka, Mustafa: Dîvân Edebiyatı’nda Münşêat Geleneği ve Hoca Neş'et'in Mektupları, (Yayımlanmamış Yüksek Lisans Tezi) İzmir: Dokuz Eylül Üniversitesi Eğitim Bilimleri Enstitüsü, 2000.

Kaya, Emel: $M u(h) y \hat{\imath} d d i n$ Mehînin Müfîd (Nazmü't-Teshîl) Adlı Eseri (İnceleme-MetinDizin) ve Bu Eserin XV. Yüzyıl Türk Tip Dilinin Oluşmasındaki Yeri, (Yayımlanmamış Doktora Tezi) Konya: Selçuk Üniversitesi SBE, 2008.

Kemikli, Bilal: "Divan Şiirinde Sağlık”, Osmanlılarda Să̆lık, I, ed. Coşkun Yılmaz ve Necdet Yilmaz, İstanbul: Biofarma 2006, s. 299-319.

Kırımlu Hafız Hüsam: Teressül (Hacı Selimăga, Nurbanu No: 122/5)-İnceleme, Transkripsiyon, Çeviri, Açıklamalar, Faksimile, haz. Şinasi Tekin, [Cambridge]: Harvard Üniversitesi Yakındoğu Dilleri ve Medeniyetleri Bölümü 2008. 
Konuk, Hamza: Vânî Mehmet Efendi’nin Münşêâtı, (Yayımlanmamış Yüksek Lisans Tezi) Kayseri: Erciyes Üniversitesi SBE, 2001.

Kur'ân-ı Kerim ve Türkçe Meâli Âlisi, haz. Ömer Nasuhi Bilmen, Ankara: Akçağ (t.y).

Kuru, Selim S.: "Mesnevî Biçiminde Aşk Hali: Birinci Tekil Şahıs Anlatılar Olarak Fürkatnâme, Heves-nâme Üzerinden Bir Değerlendirme”, Eski Türk Edebiyatı Çalışmaları IV: Nazımdan Nesire Edebî Türler (25 Nisan 2008 Bildiriler), haz. Hatice Aynur vd., İstanbul: Turkuaz 2009, s. 168-83.

Küçük Çelebi-zâde İsmầ̂l Âsım Efendi: Münşểt-ı Âsım, haz. Fahri Unan, Ankara: TTK 2013.

Kültüral, Zuhal ve Aylin Koç: "Ruhsal Hastalıklara Dair Bir Risâle: Sevdâ-yı Merâkiyye”, Türk Kültürü Incelemeleri Dergisi, 30 (2014), s. 217-44.

Kütükoğlu, Mübahat S.: Osmanlı Belgelerinin Dili (Diplomatik), İstanbul: Kubbealtı Neşriyâtı 1994.

Leylâ Hanım: Leylâ Hanım Dîvânı, haz. Mehmet Arslan, Ankara: T.C. Kültür ve Turizm Bakanlığı Kütüphaneler ve Yayımlar Genel Müdürlüğü 2018.

Mevlânâ Celâleddîn: Mektuplar, çev. ve haz. Abdülbâki Gölpınarlı, İstanbul: İnkılâp ve Aka 1963.

Nizam, Betül Sinan: "Divan Şairi Neye Hamd Eder, Niye Şükreder? Bir Anlatım Biçimi Olarak Hamd”, Türk Kültürü İncelemeleri Dergisi, 39 (2018), s. 169-222.

Okçuzâde Mehmed Şâhî, Münşe’ât, Süleymaniye Ktp., Esad Efendi, no. 3294.

Okumuş, Necdet: Muhammed bin Mahmûd Şirvânînin (XV. Yüzyıl) Göz Hastalıklarına Ait "Mürşîd" Adlı Eseri (İnceleme-Metin-Sözlük-İndeks), (Yayımlanmamış Doktora Tezi) İzmir: Ege Üniversitesi Sağlık Bilimleri Enstitüsü, 1998.

Orhonlu, Cengiz: “Telhîs”, IA, XII/I (1979), s. 148-9.

Özdemir, Fatma: Tuhfe-i Nâilî Metin ve Muhtevâ II. Cilt s. 468-734, (Yayımlanmamış Yüksek Lisans Tezi) Sivas: Cumhuriyet Üniversitesi SBE, 2011.

Özel, H. Abdülkadir: Koca Râgıb Mehmed Paşa’nın Münşêât ve Telhîsâtı (DeğerlendirmeMetin), (Yayımlanmamış Yüksek Lisans Tezi) İstanbul: Mimar Sinan Güzel Sanatlar Üniversitesi SBE, 2014.

Paksoy, Kezban: Mecmu'a-i Fevâid Konya Mevlana Müzesi Kütüphanesi 2254 (İnceleme-Metin-Tıpkıbasım), (Yayımlanmamış Yüksek Lisans Tezi) Kayseri: Erciyes Üniversitesi SBE, 2006.

Selçuk, Bahir: "Yeni Bir Sıhhât-nâme: Şehdî̀nin Sultan III. Ahmed Sıhhat-nâme’si”, Turkish Studies-International Periodical for the Languages, Literature and History of Turkish and Turkic, III/2 (2008), s. 604-16.

Seyyid Hüseyin Vehbî, Dîvân-ı Vebbî, Topkapı Sarayı Müzesi Ktp., E.H., no. 1640/1.

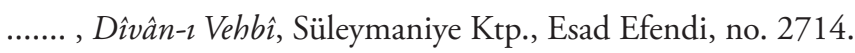


, Dîvân-ı Vebbî, Süleymaniye Ktp., Mihrişah Sultan, no. 368.

Şahin, Ebubekir: "Medh ve Hamd Kavramları Çerçevesinde Medhiye Üslûbu Üzerine", Eski Türk Edebiyatı Çalışmaları VIII: Kasîdeye Medhiye: Biçime, İşleve ve Mubtevaya Dair Tespitler, haz. Hatice Aynur vd., İstanbul: Klasik 2013, s. 340-61.

Şeref Hanım: Şeref Hanım Dîvânı, haz. Mehmet Arslan, Ankara: T.C. Kültür ve Turizm Bakanlığı Kütüphaneler ve Yayımlar Genel Müdürlüğü 2018.

Tarlan, Ali Nihat (haz.): Abmet Paşa Divanı, Ankara: Akçağ 1992.

Topal, Mehmet: Silâhdar Fındıklılı Mehmet Ăga Nusretnâme Tablil ve Metin (11061133/1695-1721), (Yayımlanmamış Doktora Tezi) İstanbul: Marmara Üniversitesi SBE, 2001.

Uzun, Mustafa: “İnşâ/Türk Edebiyatı”, DIA, XXII (2000), s. 338-9.

Woodhead, Christine: “Ottoman Inşa and The Art of Letter-Writing Influences Upon The Career of The Nişancı and Prose Stylist Okçuzade (d. 1630)", Osmanlı Araşttrmalar, VII-VIII (1988), s. 143-59.

, "Yazışma Çevreleri: Onyedinci Yüzyıl Başlarında Osmanlı Mektup Yazımı", Eski Türk Edebiyatı Çalışmaları V: Nesrin İnşâsı, haz. Hatice Aynur vd., İstanbul: Turkuaz 2010, s. 214-35.

....... The Gift of Letters: Correspondence Between Nergisi (d. 1634) and Veysi (d. 1627)", Kitaplara Vakfedilen Bir Ömre Tuhfe: İsmail E. Erünsal'a Armă̆an, II, ed. Hatice Aynur, Bilgin Aydın, Mustafa Birol Ülker, İstanbul: Ülke Armağan 2014, s. 971-88.

Yahyâ bin Mehmed el-Kâtib: Menâhicül-İnşầ (İnceleme-Metin), haz. Fahri Unan, Ankara: TTK 2014.

Yakupoğlu, Cevdet ve Namiq Musalı (haz.): Hasan b. Abdülmümin el-Hôŷ̀nin Kaleminden Selçuklu İnşâ Sanatı, Ankara: TTK 2018.

Yıldız, Sevda: 18. Yüzyıla Ait Telhis, Takrir ve Buyuruldu Mecmuası, (Yayımlanmamış Yüksek Lisans Tezi) Bilecik: Bilecik Şeyh Edebali Üniversitesi SBE, 2018.

Yıldız, Seyhan: XVIII. Yüzyıl Divan Şairi Şākir Hayatı, Eseri, Edebī Kişiliği ve Divanının Tenkidli Metni, (Yayımlanmamış Yüksek Lisans Tezi) Ankara: Gazi Üniversitesi SBE, 2002.

Yûsuf Nâbî: Münşeât-ı Nâb̂̂ (Nâbînin Mektupları), haz. Adnan Oktay, İstanbul: Türkiye Yazma Eserler Kurumu Başkanlığı Yay. 2017. 


\section{ÖRNEK METINLER:}

\section{Terkib-bend Der-Teşekkür-i Sıhhat-i Şehenşâh-1 Âlem ${ }^{i}$}

Bi-hamdillah ki âlem yine mesrûrü'l-cenân oldu Açıldı gül gibi mahzûn gönüller şâdmân oldu Efendimiz bulup sıhhat pür etdi âlemi behcet Safâ vü zevk ü sohbet âlem içre râyegân oldu Olup her gecemiz kadr oldu her bir rûzumuz bayrâm Ruh-1 zişt-i keder âyîne-i dilden nihân oldu Küsûf-1 illet olup ber-taraf cism-i şerîfinden Yine çün mihr-i enver âleme pertev-feşân oldu Amân şevketlü hünkârım bu gamla biz neler çekdik Gece gündüz işimiz nâle vü âh u figân oldu Efendim cum'alarda görmeyüp vech-i hümâyûnun Gözümüz kanlu yaş akıtmada çün erguvân oldu O günlerde koyup yüz yerlere dergâh-1 Bârîde Der idik kim İlâhî hâlimiz gâyet yaman oldu Veliyy-i ni'metimiz pâdişâhımız efendimiz Misâl-i nûr-1 nezzâre gözümüzden nihân oldu

Der-i Hakda bi-hamdillah du'âmız müstecâb oldu Hele cism-i şerîfin sıhhat ile kâm-yâb oldu II

Gidüp el-hamdülillah cism-i pâkinden o illetler Zuhûr etdi saâdetlerle sıhhatler selâmetler Bi-hamdillah kederler geçdi gayri vaktidir olsun Binişlerde safâlar zevkler dil-cûy sohbetler Sefûf $\mathrm{u}$ hab yeter vakt oldu gayri ne yensin içilsin Mürebbâlar mu'anber kahveler pâkîze şerbetler Adûnun bağrı şemşîr-i hasedle çâk çâk olsun Cihânda gösterüp şevketlü hünkârım celâletler

i Nedîm, Nedîm Dîvânı, haz. Muhsin Macit (Ankara: T.C. Kültür ve Turizm Bakanlığı Kütüphaneler ve Yayımlar Genel Müdürlüğü, 2017), s. 174-6'dan aynen alınmıştır. 
Otursun pâdişâhım haşmet ü devletle taht üzre Gelüp kılsın derinde Husrev ü Cemşîd hidmetler Keder eyyâmı gam evkâtı geçdi ba'd-ezin yâ Rab Ziyâd olsun safâlar dầim olsun izz ü devletler İlahî sana hamd olsun yine bu günleri gördük Nice günden beri derd ile tak olmuşdu tâkatlar Olup derd ü gam ile halk-1 âlem bî-dil ü bî-cân Cihânı bî-şu'ûr etmişdi mihnetler kesâfetler

Yerine geldi cânı hamdülillah rub'-1 meskûnun Efendim buldu sıhhat çok şükür cism-i hümâyûnun

III

Cihâna gelmedi bir sen gibi sultân-1 âlî-câh Hatâdan saklasın zât-1 şerîfin dâ'imâ Allah Senin nâm-1 şerîfindir tırâz u sikke vü minber Senin zât-1 hümâyûnunla fahr eyler bu izz ü câh Bu kudret ile sen ankâ-menîşsin düşmenin usfûr Bu heybet ile sen şîr-i jiyânsın düşmenin rübâh Senin hâk-i derindir Isfahânî sürme âlemde Kör olsun işidüp derd-i hasedle Isfahânda şâh $\mathrm{O}$ altun tâs ile meh peykin olmuşdur rikâbında Onunçün dầimâ gitmez yüzünden böyle gerd-i râh Bakup tûğ-1 hümâyûnundaki zerrîn mencûka Felek etmektedir hurşîd-i rahşânından istikrâh Fezâ-yı câhın içre muhtasar bir haymedir gerdûn İki altundan topdur onun üstünde mihr ü mâh Senin vakt-i şerîfinde geleydi dehre Keyhusrev Gelüp cârû-keş olurdu der-i ikbâline nâ-hâh

Bu mánî cümlenin ma'lûmudur cümle cihân içre Ki mislin gelmedi dünyâya bu devr-i zamân içre

IV

Efendim sen cihânda pâdişâh-1 bende-perversin Hudâ eksikligin göstermesin hurşîd-i enversin Nizâm-1 dîn ü devletdir senin zât-1 hümâyûnun Bu tâc u tahta ârâyiş bu mülke zîb ü zîversin 
Şehenşâh-1 muzaffer şîr-i ner sultân-ı sa'd-ahter Hidîv-i bahr u ber ferman-revâ-yı heft kişversin Olur pür-hîre çeşm-i mihre fart-1 ferr ü tâbından Firâz-1 tâc-1 ikbâl üzre bir yek-dâne gevhersin Seni gördükçe bu haşmetle der İskendere gerdûn Efendindir senin bu sen onun bâbında çâkersin Dedim ol demde ammâ ben kulun da ona bî-pervâ Behey mecnûn felek sen haddini bilmezsin ebtersin Sikender kim ki onun dergehinde ede çâkerlik Durursun da bu gûne her zamân yabana söylersin O bir sultân-ı a'zamdır ki sen her şeb gelirsin de Cebîn-i mâh ile onun derinde secde eylersin Şehenşâh ibn-i şehenşâh sultân ibn-i sultândır Ebâ-an-ced hudâvend-i cihân hakân-ı devrândır $\mathrm{V}$

İlahî sen bilirsin kalbini ol şâh-1 zî-şânın Ki dâim i'timâd u i'tikâdı sanadır onun Tevekkül eyleyüp sıdk ile lutf u cûduna dầim Recâ eyler hulûs-ı kalb ile ifzâl u ihsânın Pes imdi ey Hudâ-yı lem-yezel izz ü celâlin çün Vücûd-ı pâkini hıfzet hatâlardan o sultânın Cemâlin dâ'imâ yavuz nazardan sakla yâ Rabbî Gözün hem-çün çerâğ-1 mürde bî-nûr eyle a'dânın İlâhî dâ’imâ bi'l-cümle evlâd-ı kirâmının Husûsâ kim büyük şehzâdesi Sultân Süleymânın Kılup zât-1 şeref-pîrâların âfâtdan mahfûz Ziyâd eyle safâsın onların sûriyle dünyânın Vekîl-i mutlakı Dâmâd İbrahîm Pâşâyı Karîn et dầimâ lutfuna ol sultân-ı zî-şânın Kulûb-1 nâsı celb etmektedir çünkim şehenşâha Ziyâd et dầimâ ikbâlin ol sadr-ı cihân-bânın Hatâdan eyle yâ Rab pâdşâh-1 âlemi te’mîn Nedîmâ bendesi kılsın du'â biz diyelim âmîn 


\section{Der-'Iyâdet-i Büzürg-vârân ${ }^{\text {ii }}$}

"Letầ if-i tahiyyâtî ki ez-nesîm-i gül-zâr-1 hevâ vü bahâr koned" iii ve "vezầif-i teslîmâtî ki haber ez-nesîm-i hoş-güvâr ve na'îm-i pâyidâr u ber-karâr şeved”iv ki mahz-1 vidâd u 'ayn-1 ittihâddan fầih ü lâ'ih olur. Kavâfil-i bâd-1 sabâ ve revâhil-i sıdk u safâ birle her subh u mesâ muthef ü mühdâ kılındukdan sońra zamîr-i münîr-i âyîne-nazîr ki hâfız-1 suver-i levh-i mahfûzdur. Mahfî ve pûşîde olmaya ki zât-1 şerîf ü 'unsur-1 latîf bundan esbak niçe eyyâm câdde-i i'tidâlden cânib-i i'tilâle mẩil olup mizâc-1 mübâreke inhirâf 'ârızasınuñ ahbâr-1 nâ-sezâsı istimâ' olındukda Hakk 'alîmdür ki âteş-i gam mültehib ve leşker-i sabr muztarib olup “rûhî bi-rûhike memzûcün ve muttasılün fe-külli ârızatihi tü’zîke tü’zînî”v muktezâsınca bu cân-ı hazîne bu nev'i gam ve bu dil-i gam-gîne bu sınf elem yüz gösterüp perîşân-hâl iken muhabbir-i sâdık-1 sürûr-bahş haber-i hayât-efzâ virüp egerçi sâbıkan rûh-1 hayvânî terbiyet-i tenden 'âtıl ve kuvâ-yı cismânî tedbîr-i bedenden zâhil olup haylice muzayaka çekmişlerdür. Hâliyâ 'inâyet-i Hakîm-i ebedî ve eltâf-1 Tabîb-i sermedî yetişüp dârû-hâne-i “ve nünezzilü mine’l-Kur’âni mâ hüve şifầün ve rahmetün li'l-mü'minîne"vi şerbet-i şifâ mikdârı teşrîf-hâne-i "ve izâ maridtü fe-hüve yeşfin"den vii 'âfiyet müyesser olmışdur diyicek "el-hamdü li'llâhi'llezî ezhebe 'anne'l-hazen" viii vird-i zebân-1 şükr-gûy olup secdât-1 şükr takdîm kılındı.

Bâki'd-du'â.

El-fakîr ü zâr Mesîhî-i bî-mâr

ii Derdiyok, "Mesīhî̉nin Gül-i Sad-berg'i”, s. 267-9'dan ayın, hemze ve nazal n (ñ) dışındaki transkripsiyon işaretleri atılarak aynen alınmıştır. Arapça ve Farsça ibarelerin çevirisi Derdiyok'a aittir.

iii Gül bahçesinden esen ılık rüzgârla arzuları yerine getiren ve havayı bahar kılan saygı ve selamdan sonra.

iv İnsana hayat veren tatlı rüzgârla kararlı ve sağlam verilen haber gibi yerine getirilen vazifelerden sonra.

v Benim ruhum sizin ruhunuzla kaynaştı ve devamlı olarak hastalıktan çekindiğiniz ıstırap beni bütünüyle mustarip kıldı.

vi Kur'ân'dan indirdiğimiz şey müminlere şifa ve rahmettir (İsrâ, 17/82).

vii Hastalandığım zaman, bana O (Allah) şifa verir (Şuarâ, 26/80).

viiiBizi gam ve gussadan kurtaran Allah’a hamd olsun (Fâtır, 35/34). 


\section{'İyâdetnâme $e^{\text {ix }}$}

Her sıhhat u şifâ ve âfiyet ü safâ ki Ve nunezzilu minèl-Kur'âni mâ hüve şifẩun ve rabmetün li'l-mümminîn (K 17: 82) dârû-hânesinden nâzil olup, şerîf zâtuñuza ve latîf vücûduñuza mukârin ve mu'âvin olsun. Vezâyif-i duâ ve merâsim-i senâ ki makrûn ola, muvâzabat kılmakdan soñra i'lâm varur kim şimdikihâlde bu muhibb-i muhlis kuluñuz sem 'ine şöyle irişdi ki mübârek mizâcuñuza birez hestelik 'ârız olmış. Bu haberi işidicek hâtırumuza melâlet-i bî-hadd müstevlî olup eseri cânumuza sirâyet itdi. Irak sizden, 'azîz vücûduñuza sağlıklar yaraşur. Bu elem ve ta'ab düşmenlerünüze nasîb olsun, size yavuzluk sanan gişilere gelsün. Hakk Teâlâ nâzük vücûduñuza sıhhatlar ve râhatlar erzânî kılıvirsün. Hakk 'alîmdür ki bu kemîne muhibbünüze vâcib ve lâzımidi kim baş üzerine varup mübârek vücûdunuzı hestelik zahmetinden sormak. Ammâ 'alâyık-1 rûzigâr mâni' olduğıçün kademden kaleme ihtisâr ve iktifâ olındı. Ma'zûr tutasız. Ammâ Kâdir-i berkemâl dergâhından bi'l-gudüvvi ve'l-âsâl yüz 'acz toprağına urup hezârân tazarru' ve niyâzile şöyle istid'â ve temennâ olınur kim 'âcilen 'azîz vücûdunuza sıhhat-1 ebedî ve şifâ-yi sermedî rûzî kılup bu marazı kefâret-i seyyi'ât ve mâhî-i hat'îât idivere, inşâa'llâhu Te âlâ.

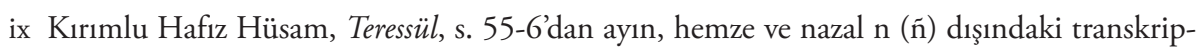
siyon işaretleri atılarak aynen alınmıştır. 